Federal Reserve Bank of Minneapolis

Research Department Staff Report 318

July 2003

\title{
What Can We Learn from the Current Crisis in Argentina?
}

\author{
Timothy J. Kehoe* \\ University of Minnesota \\ and Federal Reserve Bank of Minneapolis
}

\begin{abstract}
Currently, Argentina is experiencing what the government describes as a "great depression." Using the "Great Depressions" methodology developed by Cole and Ohanian (1999) and Kehoe and Prescott (2002), we find that the primary determinants of both the boom in Argentina in the 1990s and the subsequent depression were changes in productivity, rather than changes in factor inputs. The timing of events links the boom to the currency-board-like Convertibility Plan and the crisis to its collapse. To gain credibility, the Argentine government took measures to make abandoning the plan more costly. Because the government was unable to enforce fiscal discipline, however, these increased costs failed to make the plan more credible and instead made the crisis far worse when it failed.
\end{abstract}

*I would like to thank Kim Ruhl for research assistance, the participants at the Policy Rules Conference at Clare College, Cambridge, in September 2002 and two anonymous referees for helpful comments and suggestions, and the National Science Foundation for financial support. The data used in this paper are available at http://www.econ. umn.edu/ tkehoe/. The views expressed herein are those of the author and not necessarily those of the Federal Reserve Bank of Minneapolis or the Federal Reserve System. 


\section{Introduction}

Currently, Argentina is experiencing what the government describes as a "great depression."

The economy of Argentina finds itself submerged in a great depression that, even if it began four years ago, deepened after mid 2001 with average quarterly falls of deseasonalized GDP with respect to the previous quarter of 5 percent for the last two quarters of 2001 and the first of 2002. This violent deepening of the recession occurred just at the moment that economic agents, almost universally, became convinced of the impossibility of sustaining the Convertibility Plan. ${ }^{1}$

The currency-board-like Convertibility Plan that the Argentine government had adopted in 1991 was spectacularly successful in reducing inflation. Many commentators argue that, by fixing the value of the Argentine peso to the U. S. dollar, however, this plan resulted in an "overvaluation" of the peso. According to this popular theory, this overvaluation made the Convertibility Plan unsustainable, and the inevitable collapse of the plan produced the current crisis. (See Perry and Servin 2002 for a nuanced version of this overvaluation theory.)

As Krueger (2002) notes, Argentina's fall from grace has been dramatic. In 1999, Argentine President Carlos Menem appeared alongside U.S. President Bill Clinton at the annual meetings of the World Bank and International Monetary Fund. Argentina was the poster child for "Washington Consensus" economists and policy makers. Less than three years later, Argentina found itself in an economic depression as severe as any in a moderately industrialized country over the past century. It could only secure emergency funding from the IMF after seemingly endless negotiations.

\footnotetext{
${ }^{1}$ Dirección Nacional de Coordinación de Políticas Macroeconómicas (2002): “La economía de la Argentina se encuentra sumergida en una gran depresión que si bien se inicio hace cuatro años se profundizó desde mediados de 2001 con caídas trimestrales promedio con respecto al período anterior del 5\% del PIB desestacionalizado para los últimos dos trimestres del año pasado y el primero de 2002. Esta profundización violenta de la recesión se produjo a partir del momento en que los agentes económicos, en forma casi generalizada, se convencieron de la imposibilidad de sostener el esquema de la convertibilidad" (translation by the author).
} 
We economists will need to wait for the dust to clear from the economic wreckage in Argentina and for better data to become available to draw any firm conclusions about the causes of the current great depression there. Nevertheless, it is worthwhile to start to analyze the depression and to hypothesize about its causes. This paper does so using the "Great Depressions" methodology developed by Cole and Ohanian (1999) and Kehoe and Prescott (2002). This methodology employs growth accounting to decompose changes in economic growth rates into the parts due to capital accumulation and inputs of labor and the part due to the efficiency with which factors are used, measured as total factor productivity (TFP). The methodology also employs a simple dynamic, applied general equilibrium model, based on the neoclassical growth model, to account for the fluctuations in factor inputs that are induced by changes in TFP. In the numerical experiments of a model of Argentina presented in this paper, we find fluctuations in TFP, rather than changes in factor inputs, that were the primary determinant of both the boom in Argentina in 1991-1998 and the current depression.

The "Great Depressions" methodology is a diagnostic tool that indicates what issues need to be studied further. Perhaps not surprisingly, this methodology indicates that, when searching for causes of the boom and depression in Argentina, we should examine government policies connected with the Convertibility Plan. The results of our analysis also impose some discipline on our search: A successful theory of the recent fluctuations in Argentina needs to have the crucial link be between government policy and TFP rather than between government policy and investment or between government policy and employment.

This paper proposes an alternative to the theory that an "overvaluation" of the Argentine peso after the devaluation of the Brazilian real in 1998 produced unsustainable trade deficits and led to the crisis. This alternative theory is based on time consistency and the difficulty of enforcing fiscal discipline: In an effort to make the Convertibility Plan more credible, the Argentine administration took measures throughout the 1990s that made abandoning the plan very costly. Neither the second Menem administration nor the de la Rúa administration was able to enforce fiscal discipline, however. The desperate measures taken during 2001 to keep the Convertibility Plan in place, especially the corralito that restricted depositors' access to bank accounts, imposed tremendous 
costs on the economy. Yet these measures did not save the Convertibility Plan. Rather, the costs associated with these measures, particularly those incurred by the domestic financial system, made the crisis far worse when the Convertibility Plan failed.

\section{The Great Depressions Methodology}

Studying depressions using the neoclassical growth model is a relatively new methodology. Cole and Ohanian (1999) first applied the growth model to study the Great Depression of the 1930s in the United States. This successful application led to the study of depressions across the world using this method, including Kydland and Zarazaga's (2002) study of the 1974-1990 depression in Argentina. For more details on the methodology, as well as an extensive collection of applications, see the January 2002 Review of Economic Dynamics volume edited by Timothy J. Kehoe and Edward C. Prescott.

The great depressions methodology focuses on the growth of a country's real GDP per working-age person relative to a trend. We concentrate on GDP per workingage person instead of the more common per-capita measure since it is consistent with our theoretical economy in which the entire working-age population is capable of working. We choose to count those aged 15-64 as the working-age population.

The analysis employs a Cobb-Douglas specification of the aggregate technology,

$$
Y_{t}=A_{t} K_{t}^{\alpha} L_{t}^{1-\alpha}
$$

where $K_{t}$ is the capital stock at time $t, L_{t}$ is hours worked, and $A_{t}$ is TFP. When TFP grows at a constant rate (that is, when TFP is $A_{t}=\bar{A} g^{(1-\alpha) t}$ ), the neoclassical growth model implies a unique balanced growth path in which output and capital per worker grow at the same constant rate, $g-1$. It is relative to this trend growth rate that we measure a country's performance.

Kehoe and Prescott (2002) argue that this trend growth represents the world stock of useable production knowledge growing smoothly over time and that this knowledge is not country specific. They define the trend growth rate to be 2 percent per year, corresponding to the growth rate of GDP per working-age person for the United States 
over the period 1900-2000. Kehoe and Prescott (2002) consider the United States to be the best choice because it is a large, relatively stable country, and it is the current industrial leader. As shown in Figure 1, the 2-percent trend in GDP per working-age person fits the United States data very well, with the only major deviations from trend being the Great Depression, 1929-1940, and the World War II buildup, 1940-1946. In comparison to these major deviations, business cycle fluctuations are trivial. (Details on sources of the data are provided in Appendix A.)

The stock of world production knowledge is common across countries, but countries differ in their institutional structures. This implies that, even though all countries on a balanced growth path grow at the same rate, each country is on its own growth path. These paths differ in their levels of output per capita. Countries with institutions that encourage efficiency grow on a path with higher output per capita than countries with institutions that encourage rent seeking or other activities that lower efficiency. The institutions that determine these paths include competition policy, bankruptcy systems, and the legal system. The aspects of these institutions that affect neither labor input nor the accumulation of capital are captured in TFP. Changing institutions change the path of TFP, moving a country to a new balanced growth path. One of the central premises of the neoclassical depression methodology is that explaining movements in TFP involves identifying the changing institutions.

Figure 2 displays output per working-age person for Argentina for the years 19002002. Although our analysis focuses on economic performance in Argentina in recent years, the long-term movements in Argentina provide an interesting perspective. Argentina experienced uneven growth early in the twentieth century, with major crises during World War I and the early 1930s associated with sharp drops in world trade. Notice that between 1932 and 1974, however, Argentina grew on the 2-percent growth path, with relatively minor business cycle fluctuations. Starting in 1974, Argentina entered a great depression as defined by Kehoe and Prescott (2002).

Kehoe and Prescott (2002) consider two characteristics important in defining a great depression. First, the deviation from trend of output per working-age person must be large, and, second, this deviation must occur quickly. Their definition of a great depression is motivated by U.S. experience during 1929-1939. As shown in Figure 1, 
real output per working-age person fell by more than 37 percent compared to the 2percent growth trend between 1929 and 1933. As late as 1938, it was still almost 29 percent below trend.

Although it started more slowly than the U.S. Great Depression, the 1974-1990 great depression in Argentina lasted longer and resulted in a larger deviation in output from potential as measured by the 2-percent growth path. Figure 2 shows that between 1974 and 1990 real output per working-age person fell by almost 44 percent compared to the 2-percent growth path, with a decline of almost 25 percent in the first decade. Notice that this economic performance was horrible even ignoring the trend - real output per working-age person fell 23 percent, making the period 1974-1990 in Argentina a great depression by any reasonable definition.

Over the period 1990-1998, except for a brief downturn in 1995 associated with the Tequila Crisis, Argentina boomed, with cumulative growth almost 17 percent more than the 2-percent growth path (37 percent ignoring the trend). Starting in 1998, however, Argentina entered yet another great depression, with real output per workingage person falling by more than 29 percent by 2002 compared to the 2-percent growth path (23 percent ignoring the trend). As noted by the Argentine government in the earlier quotation, the decline was particularly severe in 2001 and 2002.

\section{Growth Accounting}

To evaluate the contributions of different factors to the changes in output per working-age person, we set up an accounting framework based on the neoclassical growth model. Using the Cobb-Douglas function (1), we calculate TFP as the residual after accounting for capital and labor,

$$
A_{t}=Y_{t} / K_{t}^{\alpha} L_{t}^{1-\alpha}
$$

Given series for $Y_{t}$ and $L_{t}$, we need to choose a value for $\alpha$ and to generate a series for $K_{t}$. Notice that, if we use capital and labor inputs as they are usually calculated, any changes in utilization rates show up in TFP. Changes in utilization rates may be important over short time horizons. 
National income accounts indicate that the share of labor compensation in GDP valued at factor prices (GDP at market prices minus indirect taxes) in Argentina is small relative to, say, that in the United States, where it is about 0.70 . Maia and Nicholson (2001), for example, estimate that this share - which corresponds to $1-\alpha$ in our production function - was between 0.517 and 0.601 in Argentina in 1993. Nevertheless, we choose a higher value of the labor share for our growth accounting and numerical experiments, $0.70-$ corresponding to $\alpha=0.30$ - for two reasons. First, measured labor compensation fails to account for the income of most self-employed and family workers, who make up a large fraction of the labor force in countries like Argentina. Maia and Nicholson (2001) try to account for this in a crude way, but Gollin (2002) shows that, for countries where there are sufficient data to adjust for this mismeasurement, the resulting labor shares tend to be close to the value in the United States. Second, a high capital share implies implausibly high rates of return on capital, which result in implausibly low values of the discount factor in our calibration. We provide alternative growth accounting and numerical experiments for a model in which $\alpha=0.45$ - corresponding to a labor share of 0.55 - in Appendix B. It may also be the case that returns to land are more important in Argentina than, say, in the United States and that this accounts for the low measured labor share. We provide an alternative growth accounting and numerical experiments for a model in which the production function is

$$
Y_{t}=A_{t} K_{t}^{\alpha_{K}} L_{t}^{\alpha_{L}} T^{\alpha_{T}}
$$

where $T$ is a fixed amount of land, $\alpha_{K}=0.30, \alpha_{L}=0.60$, and $\alpha_{T}=0.10$ in Appendix B. In neither case does the qualitative nature of our conclusions change.

To calculate a capital stock series, we cumulate investment, $I_{t}$, using

$$
K_{t+1}=(1-\delta) K_{t}+I_{t}
$$

for the depreciation rate $\delta=0.05$ and an initial condition on capital. Maia and Nicholson (2001) disaggregate investment and calculate different capital stocks for machinery and equipment, transportation equipment, residential housing stock, and so on. Each different capital stock has a different depreciation rate. The weighted average of their 
depreciation rates over the period 1961-2002 is 0.048. Using data from Meloni (1999) and Kydland and Zarazaga (2002) we are able to construct series of output and investment going back to 1918 . We impose the somewhat arbitrary initial condition that the capital stock in 1918 be such that the capital-output ratio grew at the same rate as it did over 1919-1928.

Given our choice of $\alpha$ and the generated series for $K_{t}$, we can calculate a TFP series. Taking natural logarithms of the production function, we follow Hayashi and Prescott (2002) in rearranging terms to obtain

$$
\log \left(\frac{Y_{t}}{N_{t}}\right)=\frac{1}{1-\alpha} \log A_{t}+\frac{\alpha}{1-\alpha} \log \left(\frac{K_{t}}{Y_{t}}\right)+\log \left(\frac{L_{t}}{N_{t}}\right),
$$

where $N_{t}$ is the number of working-age persons. The first term on the right-hand side of this equation is the contribution to output of TFP, the second is the contribution of the capital-output ratio, and the third is the contribution of hours worked per working-age person. On a balanced growth path, output per worker and capital per worker grow at the same rate, and the capital-output ratio and hours worked per working-age person are constant. On such a path, our growth accounting would attribute all growth to changes in TFP. In our growth accounting, therefore, changes in the second two terms measure the contributions of deviations from balanced-growth behavior: changes in the investment rate and changes in hours worked per person.

Figure 3 depicts the strikingly similar fluctuations in real GDP per working-age (15-64) person and total factor productivity over the period 1970-2002. The correlation between the yearly changes in the two series is 0.96 . The first column in Table 1 presents the growth accounting for Argentina during the periods 1990-1998 and 19982002, as well as for the 1974-1990 great depression that confirms the impression given by Figure 3: Most of the economic fluctuations in output per working-age person $Y_{t} / N_{t}$ are due to changes in total factor productivity $A_{t}$, rather than to changes in the capitaloutput ratio $K_{t} / Y_{t}$ or in the hours per working-age person $L_{t} / N_{t}$. 


\section{Applied General Equilibrium Model}

Although growth accounting indicates that most of the changes in output in Argentina over the period 1970-2002 were due to changes in TFP, the contributions of changes in the capital-output ratio and of changes in hours worked per working-age person were not negligible. How much of these changes can we account for as equilibrium responses to the observed productivity shocks in a growth model? To answer this question, we calibrate a simple applied general equilibrium model, based on the neoclassical growth model, of a closed economy in which consumers have perfect foresight over the sequence of TFP shocks. The representative consumer maximizes the utility function

$$
\sum_{t=1970}^{\infty} \beta^{t}\left[\gamma \log C_{t}+(1-\gamma) \log \left(\bar{h} N_{t}-L_{t}\right)\right]
$$

subject to the budget constraint in each period,

$$
C_{t}+K_{t+1}-K_{t}=w_{t} L_{t}+\left(r_{t}-\delta\right) K_{t}
$$

and an initial condition on capital, $K_{1970}$. Here $C_{t}$ is consumption, $\bar{h}$ is the number of hours available, taken to be 100 hours per week, 52 weeks per year for working-age persons, and $\left(\bar{h} N_{t}-L_{t}\right)$ is leisure. In addition, $r_{t}$ and $w_{t}$ are the marginal products of the production function with respect to $K_{t}$ and $L_{t}$.

Given the production technology that we have used for growth accounting, the feasibility constraints for this model are

$$
\begin{gathered}
C_{t}+K_{t+1}-(1-\delta) K_{t}=A_{t} K_{t}^{\alpha} L_{t}^{1-\alpha} \\
K_{t+1}=(1-\delta) K_{t}+I_{t} \\
C_{t}, I_{t} \geq 0 .
\end{gathered}
$$

Here we include government spending and net exports in consumption. To run numerical experiments, we need to calibrate values for the parameters $\beta$ and $\gamma$ in the consumer's utility function. Using the first-order conditions for the maximization problem of the representative consumer in our model economy, we obtain

$$
\beta=\frac{C_{t}}{C_{t-1}\left(1+r_{t}-\delta\right)}
$$




$$
\gamma=\frac{C_{t}}{C_{t}+w_{t}\left(\bar{h} N_{t}-L_{t}\right)} .
$$

Using the data for the period 1950-1970, we estimate $\beta=0.9445$ and $\gamma=0.2666$.

The second column in Table 1 and the first columns of graphs in Figures 4, 5, 6, and 7 report the results of our base case numerical experiment. We set $K_{1970}$ equal to its observed value in 1970 and compute the perfect foresight equilibrium path where the sequence of TFP, $A_{1970}, A_{1971}, \ldots, A_{2002}$, is given by data and TFP after 2002 is assumed to grow at the same average rate as it did over the period 1950-2002. The model is truncated by assuming that the equilibrium converges to the balanced growth path by 2015. Notice that, although the model captures the timing of ups and downs in Argentina fairly well, fluctuations are too large compared to the data. This especially shows up in fluctuations in hours worked in Figure 5 and in the investment rate in Figure 7. Notice, for example, that the nonnegativity constraint on investment (10) actually binds in 1990.

There are a number of reasons why our model may predict more volatile swings in hours worked and investment than in the data. The assumption of perfect foresight, for example, may be too strong. Notice, for example, that the model has the downturn in the investment rate associated with the current depression start in 1998, rather than in 1999 as in the data. A model with uncertainty and rational expectations would tend to produce a less volatile path for investment than that in Figure 7, and a smoother capital accumulation would tend to induce a smoother labor input than that in Figure 5. Rigidities in the Argentine labor market, on the other hand, may have caused hours worked to fluctuate less than in the frictionless labor market in our model, causing hours worked to fluctuate less than in Figure 5. These are obviously topics that need to be studied more.

To show that introducing frictions into the model can result in far more accurate results, we introduce the simplest possible friction into capital accumulation. The third and fourth columns in Table 1 and the second columns of graphs in Figures 4, 5, 6, and 7 report the results of numerical experiments in which there are constant-returns-to-scale adjustment costs of the capital stock as in Lucas and Prescott (1971):

$$
C_{t}+I_{t}=A_{t} K_{t}^{\alpha} L_{t}^{1-\alpha}
$$




$$
K_{t+1}=(1-\delta) K_{t}+\phi\left(I_{t} / K_{t}\right) K_{t}
$$

where

$$
\phi(I / K)=\left[\delta^{1-\eta}(I / K)^{\eta}+(\eta-1) \delta\right] / \eta .
$$

The model without adjustment costs corresponds to $\eta=1$.

Somewhat arbitrarily, we set $\eta=0.9$, as in Fernandez de Cordoba and Kehoe (2000). Since capital accumulation is now governed by equation (14), rather than by equation (4), we need to recalculate our capital stock series and our TFP series. The third column of Table 1 reports the growth accounting. The calibration of $\gamma$ stays the same, and we recalibrate $\beta=0.9544$. The results of the numerical experiment are reported in the fourth column in Table 1 and the second column of graphs in Figures 4, 5, 6, and 7. Notice that the primary determinant of changes in GDP is still changes in TFP. As King and Rebelo (1999) have noted, putting rigidities into a dynamic general equilibrium model does not diminish the role played by TFP shocks.

The model now does a more accurate job of accounting for fluctuations in Argentina. Notice, in particular, that the smoother investment series in Figure 7, which is the direct result of the adjustment costs, induces a smoother series for hours worked in Figure 5. There are still significant deviations of the model's results from the data that are worth studying. Hours worked in Argentina during the boom of 1990-1998 actually fell, for example, rather than rose as in the model. We obviously need to identify the factors that caused this sort of deviation between the data and the model's predictions. We also need to do a better job in specifying and calibrating the frictions that we impose either in the labor market or in capital accumulation. Nevertheless, examining the results of our numerical experiments in Table 1 and Figures 4, 5, 6, and 7 indicates that a model that takes the series for TFP as given can account for most of the boom in Argentina in the 1990s and the current depression there. Consequently, to explain what has happened in Argentina, we need to be able to explain the performance of TFP. 


\section{Explaining TFP}

It should be stressed that the "Great Depressions" methodology does not always find that changes in TFP growth drive changes in economic growth - Conesa and Kehoe (2003), for example, find that changes in hours worked have driven the economic slowdown in Spain over the period 1975-2000. As Kehoe and Prescott (2002) conclude, however, changes in TFP are the most common determinants of great depressions. In attempting to account for cross-country levels of output per capita, Prescott (1998) also concludes that only TFP can account for these differences, and not capital or labor inputs. Consequently, we need to understand TFP to explain both the cross-country distribution of per capita output, and the large movements of output within a specific country. Prescott (1998) calls for a theory of TFP and outlines a theory that involves a country's resistance to the adoption of more efficient technologies.

While there is no broadly accepted theory of TFP, a country's institutions likely play a large role in the evolution of its TFP. Institutions that may be important include a country's openness to foreign competition, the strength of monopoly rights, the prevalence of labor unions, government regulation of industry, and price controls. To understand the boom of the 1990s and the depression that started in 1998 in Argentina, we need to identify changes in the institutional structure that took place around the beginning of the boom and the beginning of the depression. We do not need to go too far in searching for obvious candidates. In 1991, the Argentine government introduced the Convertibility Plan to reduce inflation. And, as the quote from the Argentine government reported in the introduction makes clear, the timing of the current depression identifies it with the collapse of this policy.

In the next section, we return to the situation in Argentina. At this point, however, we note that the finding that changes in government policy are the primary causes of economic booms and depressions is consistent with the findings in the KehoePrescott volume. Bergoeing, Kehoe, Kehoe, and Soto (2002), for example, study the depressions that began in the early 1980s in Chile and Mexico. They conclude that exogenous shocks like the deteriorations in the terms of trade and the increases in foreign interest rates that buffeted Chile and Mexico in the early 1980s can cause a decline in 
economic activity of the usual business cycle magnitude. It is government policy, however, that can turn such a decline into the severe and prolonged drop in economic activity below trend that constitutes a great depression.

Chile and Mexico, like most Latin American countries, experienced severe economic crises in the early 1980s. Their recovery paths differed markedly. In Chile, output per working-age person returned to a 2-percent trend growth path in about a decade and since then has grown faster than trend. In Mexico, output never fully recovered and two decades later is still 30 percent below trend.

The explanation of Bergoeing et al. (2002) for the difference in economic performance in Chile and Mexico is based on the different timing of structural reforms in the two countries. Chile undertook reforms in the 1970s and early 1980s in trade policy, fiscal policy, privatization, banking, and bankruptcy laws that set the stage for the successful performance of the late 1980s and 1990s. Mexico postponed most of these reforms and stagnated. As in this paper, Bergoeing et al. (2002) perform numerical experiments with simple applied general equilibrium models. These numerical experiments indicate that the only reforms that can explain the difference in economic performance are those that show up primarily as differences in productivity, not reforms that show up as differences in factor inputs. This result rules out fiscal reforms, which primarily affect the incentives to accumulate capital and to work. Moreover, the timing is not right for fiscal reforms as an explanation: Both Chile and Mexico reformed their tax systems in the mid-1980s, so these cannot account for the different paths. The matter of timing is crucial. Bergoeing et al. (2002) hypothesize that reforms in trade policy and privatization were less important than those in banking and bankruptcy law precisely because Chile had already reaped most of the benefits of these reforms while Mexico was starting to reap them precisely when Mexico was stagnating and Chile was growing. The crucial difference is that Chile was willing to pay the costs of reforming its banking system and of letting inefficient firms go bankrupt while Mexico was not. The contrast between Chile and Mexico can provide important lessons for Argentina as it emerges from the current crisis. 


\section{What Happened to TFP in Argentina?}

The analysis of the previous sections leaves us with the challenge of identifying the policy changes that led to the fluctuations in TFP depicted in Figure 3. This section sketches out the elements of a theory that ascribes the spurt in growth in TFP in the early 1990s to the sharp drop in inflation associated with the implementation of the Convertibility Plan in 1991 and the sharp fall in TFP in 2001 and 2002 to the collapse of this plan. In this theory, the time consistency problem associated with coordinating monetary and fiscal policy plays a crucial role. It will be worthwhile to expand this sketch of a theory into a formal model, especially as more data become available.

\section{The Convertibility Plan and Declining Inflation}

As the data in Figure 8 show, between 1970 and 1991 Argentina suffered from chronically high inflation, punctuated by bouts of hyperinflation. In both 1989 and 1990 inflation in the consumer price index was measured in thousands of percent. In 1991 the newly elected President of Argentina, Carlos Menem, launched the currency-board-like Convertibility Plan to reduce inflation. The architect of this plan was Menem's Economics Minister, Domingo Cavallo. The Convertibility Plan tied the value of the new Argentine peso to that of the U.S. dollar and was spectacularly successful in reducing inflation. Between 1992 and 2001 CPI inflation averaged about 4 percent per year with prices actually falling slightly over the period 1999-2001. ${ }^{2}$

Although the Convertibility Plan was successful in reducing inflation, it suffered from credibility problems as evidenced by occasional spikes in interest rates. Figure 9 shows significant spikes in interest rates on peso denominated deposits in 1992 and 1993, during the early days of the Convertibility Plan, in 1995, during the Tequila Crisis, and starting in late 2000. These spikes can be ascribed to fears on the part of investors that the Convertibility Plan would be abandoned and the peso would be devalued. Starting in 1994, interest rates on dollar denominated deposits also had spikes during the same periods. These spikes can be ascribed to fears that any abandonment of the

\footnotetext{
${ }^{2}$ Hyperinflation and subsequent deflation make graphing the inflation rate in Figure 8 difficult. The data in Figure 8 are calculated using $\log _{2}\left(P_{t} / P_{t-1}\right)$ rather than $\log _{2}\left(P_{t} / P_{t-1}-1\right)$.
} 
Convertibility Plan would be accompanied by some sort of collapse of the domestic financial system associated with drastic changes in government policies. Later events have proved these fears justified.

Comparing Figure 3 with Figure 8 presents us with the challenge of modeling the link between changes in TFP and inflation or changes in inflation. The results of the numerical experiments with our general equilibrium model impose some discipline on any potential theory. In particular, the impact of changes in inflation would have to show up primarily in TFP or in the adjustment costs, rather than in investment. Notice that Figure 7 shows that the investment rate in the Argentine data was actually somewhat higher during the high inflation depression than the model would have predicted. Notice too that the model does a good job of accounting for the collapse in investment in 2001 and 2002 as a response to plummeting productivity.

\section{Foreign Trade}

The Brazilian devaluation in 1998 did not lead to problems for the Argentine current account - both exports and the trade surplus in fact grew, except for a mild downward blip in 1999. Direction of trade statistics show that an increase in exports to the United States more than compensated for the decline in exports to Brazil. Argentine exports are primarily agricultural products, especially beef and wheat, whose prices are determined on world markets. The sharp change in Argentina's terms of trade with Brazil undoubtedly hurt some specific industries, such as the automobile parts industry. It is conceivable that these negative impacts had significant macroeconomic spillovers. Nonetheless, Figure 10 shows that no theory that places the blame for the crisis on a drop in the trade balance can match the data.

What is even more striking about the data depicted in Figure 10 than the movements in the trade statistics - at least up until 2002 - is the very low level of the ratio of foreign trade to GDP. Argentina, like its MERCOSUR partner Brazil, is a closed economy compared to, say, Chile or Mexico, where imports plus exports are roughly 3 times larger as a fraction of GDP. It is possible that the relatively closed nature of Argentina made it more susceptible to terms of trade shocks like that caused by the Brazilian devaluation. 


\section{Foreign Investment}

Foreign investment probably played a significant role in both the 1990s boom and the current crisis. The current crisis can be thought of as an example of what Calvo, Izquierdo, and Telvi (2002) call a "sudden stop" - a situation where foreign investment, which has mostly poured into the nontraded goods sector, suddenly stops and Argentines are asked to start to repay their debts. As a country with a small traded goods sector and many rigidities that impede the mobility of factors across sectors, Argentina is finding this adjustment very painful. Figure 11, which compares data on foreign direct investment in Argentina with those in Chile, illustrates the challenge that construction of any such model along these lines will face. At the same time that Argentina was faced with its sudden stop, Chile was hit with an even larger one, yet did not fall into a similar crisis.

\section{Lack of Fiscal Discipline}

The proposed hypothesis is that the Argentine crisis was triggered by a lack of political consensus to control the fiscal deficit. The crucial events occurred in March 2001: On 16 March, President Fernando de la Rúa rejected the plan presented by the Economics Minister, Ricardo López Murphy, to reduce the fiscal deficit. After López Murphy's resignation, de la Rúa appointed Domingo Cavallo, the architect of the Convertibility Plan during the Menem administration, as Economics Minister. Cavallo presented a new economic plan in the lower house of Argentina's congress. On 28 March, however, the congress refused to allow Cavallo to cut government salary and pension costs, and the government sold debt to cover the deficit. In December 2001, the government defaulted on its debt and, in January 2002, it abandoned the Convertibility Plan.

While Krueger (2002) puts forward arguments and some data to support this hypothesis, more work on the data needs to be done. Figure 12, for example, based on official Argentine data, shows a small and declining federal government deficit prior to the crisis. Figure 13, based on data put together by the International Monetary Fund and 
presented by Krueger, includes provincial finances and off budget items. It depicts a far direr situation.

As Da Rocha, Giménez, and Lores (2002) stress, abandoning the Convertibility Plan has had a disastrous effect on Argentina's government finances. The real devaluation that has followed has made the value of government debt, most of which is denominated in dollars, shoot up, as seen in Figure 14. Unless there is a substantial real appreciation, Argentina will find the burden of this debt crushing.

Evidence of a lack of consensus in Argentina is easy to find. In the summer of 2001 when Cavallo pushed a Zero Deficit Law through Congress to restrict government spending, the provinces and even other departments of the federal government reacted by issuing their own quasi-monies to make up for funds they would not be able to receive. Figure 15 depicts a Patacón, an interest-bearing bond issued by the government of the Province of Buenos Aires. Quasi-monies of this sort can be quickly distinguished by the contract printed on the reverse side that is contained in the law authorizing their issue. By early 2002, these sorts of bonds had a nominal value equal to about 45 percent of the value of domestic currency in circulation (de la Torre, Yeyati, and Schmukler 2002). Significantly, the value of the Patacón depicted in Figure 15, one peso, is lower than that of any paper currency.

\section{Lessons for Models of Monetary Policy}

Perhaps the most important challenges in the design of monetary policy involve trying to overcome dynamic consistency problems. The Argentine experience provides us with at least four important lessons.

\section{Real Exchange Rates and Domestic Relative Prices}

The "New Open Economy Macroeconomics" stresses price rigidities and pricing to market in constructing mechanisms through which monetary policy affects real exchange rates. See Betts and Devereux (2000) and Chari, Kehoe, and McGrattan (2002) for carefully worked out models. This approach, at least as it has been developed so far, provides no role for the relative price of nontraded goods to traded goods within a 
country. This approach has been supported by empirical work by Engel (1999), which finds little or no relation between real exchange rate fluctuations and fluctuations in the relative price of nontraded goods. It is doubtful that this approach will be useful in modeling events in Argentina, however. Figure 16 shows the wild fluctuations in the real exchange rate between Argentina's currency and the U.S. dollar and the fluctuations in the portion of this real exchange rate due to changes in the relative price of nontraded goods. Here CPIs are used to measure overall price levels, and PPIs are used to measure traded goods prices (see Betts and Kehoe 2003 for details). Changes in the relative price of nontraded goods, even measured as crudely as they are in Figure 16, account for more than 50 percent of real exchange rate fluctuations.

A promising direction for modeling real exchange rate fluctuations in Argentina is given by Fernandez de Cordoba and Kehoe (2000), who relate real exchange rate fluctuations to changes in the relative price of nontraded goods and to changes in foreign investment. Monetary policy seems to have played a crucial role in driving foreign investment in Argentina, but not through the mechanisms stressed by the New Open Economy Macroeconomics.

\section{Commitment and the Costs of Reneging}

Increasing the costs of abandoning a policy can reduce the set of conditions under which a crisis can occur. If these increased costs do not rule out a crisis completely, however, they can backfire in making the economy far worse off if things do go wrong. Cole and Kehoe $(1996,2000)$ stress this point in a calibrated general equilibrium model of Mexico's 1994-1995 financial crisis. In studying the boom in the 1990s in Argentina and the subsequent collapse, we will have to carefully examine government policies that accompanied the Convertibility Plan as part of the overall stabilization policy. Particularly important policies include the massive privatization, especially in the banking system, and liberalization of the financial system in general. Significantly, these policies allowed the Argentine economy to become "semi-dollarized." See de la Torre et al. (2002) for an analysis of the real costs incurred by abandoning the Convertibility Plan. 


\section{"Conservative" Central Bankers}

Rogoff's (1985) (and, more recently, Woodford's 2002) proposal to reduce the dynamic consistency problem in monetary policy making is to employ a "conservative" central banker, one whose social welfare function puts far more weight on price stability than does the general population's. This is what the de la Rúa administration tried to do in bringing in Domingo Cavallo as Economics Minister in early 2001. Yet this strategy backfired when Cavallo failed to control fiscal accounts and the issue of currency-like bonds by the provinces.

\section{The Political Economy of Monetary Policy}

Dynamic consistency problems are pervasive because commitment is not easy. Lack of political consensus both within the federal government and between the federal and the provincial governments in Argentina made it impossible to resolve fiscal imbalances. In this environment, "unpleasant monetarist" arithmetic doomed the Convertibility Plan to failure. Measures that the administration had put in place to make the Convertibility Plan more credible are imposing severe costs on the economy now that the plan has failed.

During the de la Rúa administration, many politicians, both in the provinces and within the federal government itself, were happy to see the policies put forward by the Economics Ministry fail. (See Buscaglia (2002) for a discussion.) Any modeling approach that depends on a single agent called "the government" and which maximizes a social welfare function is sure to miss this crucial aspect of the Argentine saga.

\section{A Final Note}

They say that every dark cloud has a silver lining, but it is hard to have much optimism about the Argentine economy. Nevertheless, the pervasiveness of time consistency problems may have recently produced a favorable outcome for Argentina: Up until the summer of 2002, both the Bush administration and the International Monetary Fund in the person of its new Managing Deputy Director Anne Krueger claimed to be committed to a policy of "no more bailouts" for countries like Mexico and 
Korea that run into financial crises of their own making. In August 2002, however, the IMF, with the backing of the U.S. government, announced large loan packages for Brazil and Uruguay, and negotiations for another package for Argentina started. This loan package was finally approved in January 2003.

Recent data from Argentina show a modest turnaround in quarterly GDP growth and a more significant exchange rate appreciation. The political situation is uncertain, but there is some hope that the economic depression is bottoming out. What is more certain is that, as more data become available, Argentina will provide an important and fascinating case study for economic researchers to study. 


\section{References}

Bergoeing, R., P. J. Kehoe, T. J. Kehoe, and R. Soto (2002), “A Decade Lost and Found: Mexico and Chile in the 1980s," Review of Economic Dynamics, 5, 166-205.

Betts, C. M. and M. B. Devereux (2000), "Exchange Rate Dynamics in a Model of Pricing-to-Market," Journal of International Economics, 50, 215-244.

Betts, C. M. and T. J. Kehoe (2003), "U.S. Real Exchange Rate Fluctuations and Relative Price Fluctuations," University of Minnesota and University of Southern California.

Buscaglia, M. A. (2002), “The Economics and Politics of Argentina’s Debacle," Universidad Austral.

Calvo, G. A, A. Izquierdo, and E. Telvi (2002), "Sudden Stops, the Real Exchange Rate, and Fiscal Sustainability: Argentina's Lessons," Inter-American Development Bank.

Chari, V. V., P. J. Kehoe, and E. R. McGrattan (2002), "Can Sticky Price Models

Generate Volatile and Persistent Real Exchange Rates?" Review of Economic Studies, 69, 533-563.

Cole, H. L. and T. J. Kehoe (1996), “A Self-Fulfilling Model of Mexico's 1994-95 Debt Crisis," Journal of International Economics, 41, 309-330.

Cole, H. L. and T. J. Kehoe (2000), "Self-Fulfilling Debt Crises," Review of Economic Studies, 67, 91-116.

Cole, H. L. and L. E. Ohanian (1999), "The Great Depression in the United States from a Neoclassical Perspective," Federal Reserve Bank of Minneapolis Quarterly Review, 23, $2-24$.

Conesa, J. C. and T. J. Kehoe (2003), "Productivity, Taxes, and Hours Worked in Spain 1975-2000," University of Minnesota.

Da Rocha, J. M., E. L. Giménez, and F. X. Lores (2002), "Devaluation Beliefs and the Argentinian Debt Crisis," Universidade de Vigo.

de la Torre, A., E. Levy Yeyati, and S. L. Schmukler (2002), “Argentina’s Financial Crisis: Floating Money, Sinking Banking," World Bank.

Dirección Nacional de Coordinación de Políticas Macroeconómicas (2002), “La Actividad Económica y el Empleo después de la Depreciación Real del Peso," Dirección Nacional de Coordinación de Políticas Macroeconómicas, Secretaría de Política Económica, Argentina.

(http://www.mecon.gov.ar/peconomica/docs/informe_coyuntura1.pdf) 
Elías, V. J. (1992), Sources of Growth: A Study of Seven Latin American Countries, San Francisco: ICS Press.

Engel, C. (1999), “Accounting for U.S. Real Exchange Rate Changes,” Journal of Political Economy, 107, 507-538.

Fernandez de Cordoba, G. and T. J. Kehoe (2000), "Capital Flows and Real Exchange Rate Fluctuations Following Spain's Entry into the European Community," Journal of International Economics, 51, 49-78.

Gollin, D. (2002), “Getting Income Shares Right,” Journal of Political Economy, 110, 458-474.

Hayashi, F. and E. C. Prescott (2002), “The 1990s in Japan: A Lost Decade,” Review of Economic Dynamics, 5, 206-235.

Kehoe, T. J. and E. C. Prescott (2002), "Great Depressions of the Twentieth Century," Review of Economic Dynamics, 5, 1-18.

King, R. and S. Rebelo (2000), "Resuscitating Real Business Cycles," in J. Taylor and M. Woodford, editors, Handbook of Macroeconomics, North-Holland, 927-1007.

Krueger, A. O. (2002), "Crisis Prevention and Resolution: Lessons from Argentina," International Monetary Fund.

(http://www.imf.org/external/np/speehes/2002/071702.htm)

Kydland, F. E. and Zarazaga, C. E. J. M. (2002), “Argentina's Lost Decade,” Review of Economic Dynamics 5, 152-165.

Lucas, R. E. and E. C. Prescott (1971), “Investment Under Uncertainty,” Econometrica, $39,659-681$.

Maddison, A. (1995), Monitoring the World Economy, 1820-1992, Paris: Development Center, Organisation for Economic Co-operation and Development.

Maia, J. L. and P. Nicholson (2001), "El Stock de Capital y la Productividad Total de los Factores en Argentina,” Dirección Nacional de Coordinación de Políticas Macroeconómicas, Secretaría de Política Económica, Argentina.

Meloni, O. (1999), “Crecimiento Potencial y Productividad en la Argentina: 19801997," Universidad Nacional de Tucumán.

Perry, G. and L. Servin (2002), "The Anatomy of a Crisis: Why Was Argentina Special and What Can We Learn from It?" World Bank. 
Prescott, E. C. (1998), "Needed: A Theory of Total Factor Productivity," International Economic Review, 39, 525-551.

Rogoff, K. (1985), “The Optimal Degree of Commitment to an Intermediate Monetary Target," Quarterly Journal of Economics, 100, 1169-1190.

Woodford, M. (2002), “Optimal Interest Rate Smoothing,” Princeton University. 


\section{Appendix A: Data Sources}

The data used in this paper are available at http://www.econ.umn.edu/ tkehoe/. Details on the sources of the data are provided below.

\section{National Income and Product}

Argentina's national income and product account data for the years 1970-2002 are from the International Monetary Fund's International Financial Statistics CD-ROM. The components of gross domestic product (private consumption, government consumption, investment, imports and exports) were deflated by the gross domestic product deflator. Data on real GDP 1950-1970 and on investment 1918-1970 are from Kydland and Zarazaga (2002), which are originally sourced from Meloni (1999). Additional data on exports and imports are taken from the International Monetary Fund's Direction of Trade Statistics CD-ROM. The data on real GDP 1900-1950 is from Maddison (1995).

GDP data for the United States for the years 1948-2000 are from the International Monetary Fund's International Financial Statistics CD-ROM (IFS). Data on GDP for the United States from 1920-1948 are from Maddison (1995). Data on working-age population for the United States are from the U.S. Census Bureau.

\section{Population and Hours Worked}

Data on population and population 15-64 in Argentina for the years 1960-2000 are from the World Bank's World Development Indicators CD-ROM. The data for population 1900-1960 are from Maddison (1995). These data have been spliced with the series for population 15-64 in 1960. Estimates for population and population 15-64 2001-2002 are obtained by extrapolation. The data on hours worked 1974-2002 are estimated from the data reported by the Instituto Nacional de Estadística y Censos in its Encuesta Permanente de Hogares (http://www.indec.mecon.ar). These data, based on surveys of urban areas that contain about 65 percent of the population, report on the percentage of population that is working either part time or full time. Full-time work is assumed to be 40 hours per week, and part-time is assumed to be 20 hours. Data are 
averaged over the two surveys per year. (The data from the August surveys are ignored for 1998 and 1999, when there were three surveys.) These percentages are then applied to the data for total population to obtain a series for hours worked. This series is spliced with data from Kydland and Zarazaga (2002) for 1950-1973, which were constructed using data from Elías (1992) and from the Encuesta Permanente de Hogares.

\section{Government Finances}

The quarterly data on government revenue and expenditures for Argentina are from the Secretaría de Hacienda's web site (http://www.mecon.gov.ar/onp/html). These data cover total revenue and total expenditure for the federal government. The quarterly data that serve as the denominator in Figure 12 are from the IFS. The data depicted in Figure 13 are meant to be more comprehensive. They are from Krueger (2002).

\section{External Debt and Foreign Direct Investment}

Data on Argentina's external debt 1986-2001 are from the World Bank's World Development Indicators CD-ROM. The 2002 observation is from the Joint BIS-IMFOECD-WB data base (http://www.imf.org/external/np/sta/ed/joint.htm). The data on foreign direct investment in Argentina and in Chile are from the IFS, as are the data on GDP in Chile.

\section{Prices}

The data on Argentina's consumer and producer price indices and the nominal exchange rate are from the IFS. The monthly interest rate series are the money market rate for peso deposits and the money market rate for foreign currency deposits from the IFS. 


\section{Appendix B: Sensitivity Analysis}

Table 2 presents the results of models with a low labor share, $1-\alpha=0.55$. For this case, we calibrate $\gamma=0.3162$ and $\beta=0.8867$ for the base case model and $\beta=0.8884$ for the model with adjustment costs. Notice that, because the large capital share $\alpha=0.45$ implies a high return on capital, the discount factor $\beta$ is much lower than values typically calibrated for models in which periods are years. One possibility is that taxes on capital, either explicit or implicit, were abnormally high in Argentina. If we were to explicitly incorporate high capital taxes into the model, what would matter for the estimation of $\beta$ is the after-tax return on capital. This is a possibility worth exploring.

The most important thing to notice about the results of the numerical experiments reported in Table 2 is how similar they are to those reported in Table 1. The growth accounting decomposition in equation (5) leads us to expect that in the model with the low labor share more of economic fluctuation will be ascribed to changes in the capitaloutput ratio and less to changes in TFP. Changing $\alpha$ implies that the TFP series also changes, however. In fact, the results in Table 2 show that the new TFP series is far more volatile than the old one and that even more of the movement in output is ascribed to it. Nevertheless, the model still does a good job of matching the data, particularly when we introduce capital adjustment costs.

Table 3 presents the results of models in which there is a fixed factor, land, that earns 10 percent of GDP. This is a reasonable upper bound on the economic importance of land given that agriculture and mining only account for about 10 percent of GDP in Argentina: land earns a return in other sectors, but labor and capital also earn returns in agriculture and mining. Because there is a fixed factor, the only balanced growth paths are ones in which there is no growth. Accordingly, we calculate the equilibria summarized in Table 3 by requiring that TFP growth and population growth after 2010 converge to zero and that the equilibrium converge to a zero growth steady state by 2035 . Calibrating the model without adjustment costs, we find that $\beta=0.9445$, as in the model without land, and that $\gamma=0.2977$. In the model with adjustment costs, $\beta=0.9445$ 
(actually 0.94451 as opposed to 0.94454 in the model without adjustment costs) and $\gamma$ remains the same.

The results presented in Table 3 are very similar to those in Table 1. If anything, the model now does a better job of matching the data. Notice that changes in TFP growth still play the crucial role in driving changes in GDP growth. 


\section{Table 1}

Growth accounting:

Decomposition of average annual changes in real output per working-age person (percent)

\begin{tabular}{|c|rr|rr|}
\hline & \multicolumn{2}{|c|}{ base case } & \multicolumn{2}{c|}{ adjustment costs } \\
& data & model & data & model \\
\hline depression 1974-1990 & & & & \\
change in Y/N & -1.60 & -3.00 & -1.60 & -2.52 \\
due to TFP & -2.61 & -2.61 & -2.63 & -2.63 \\
due to K/Y & 1.38 & 1.04 & 1.40 & 1.01 \\
due to L/N & -0.37 & -1.43 & -0.37 & -0.90 \\
\hline boom 1990-1998 & & & & \\
change in Y/N & 3.90 & 6.83 & 3.90 & 5.82 \\
due to TFP & 6.11 & 6.11 & 6.10 & 6.10 \\
due to K/Y & -1.76 & -2.20 & -1.75 & -2.08 \\
due to L/N & -0.45 & 2.92 & -0.45 & 1.80 \\
\hline depression 1998-2002 & & & & \\
change in $\mathrm{Y} / \mathrm{N}$ & -6.64 & -6.34 & -6.64 & -5.20 \\
due to TFP & -5.95 & -5.95 & -5.96 & -5.96 \\
due to K/Y & 2.91 & 4.01 & 2.92 & 3.18 \\
due to $\mathrm{L} / \mathrm{N}$ & -3.60 & -4.40 & -3.60 & -2.42 \\
\hline
\end{tabular}




\section{Table 2}

\section{Growth accounting: \\ Decomposition of average annual changes in real output per working-age person (percent): model with low labor share}

\begin{tabular}{|c|rr|rr|}
\hline & \multicolumn{2}{|c|}{ base case } & \multicolumn{2}{c|}{ adjustment costs } \\
& data & model & data & model \\
\hline depression 1974-1990 & & & & \\
change in Y/N & -1.60 & -3.37 & -1.60 & -2.87 \\
due to TFP & -3.87 & -3.87 & -3.90 & -3.90 \\
due to K/Y & 2.64 & 1.79 & 2.67 & 1.83 \\
due to L/N & -0.37 & -1.29 & -0.37 & -0.80 \\
\hline boom 1990-1998 & & & & \\
change in Y/N & 3.90 & 6.45 & 3.90 & 5.46 \\
due to TFP & 7.70 & 7.70 & 7.68 & 7.68 \\
due to K/Y & -3.35 & -4.01 & -3.33 & -3.88 \\
due to L/N & -0.45 & 2.76 & -0.45 & 1.66 \\
\hline depression 1998-2002 & & & & \\
change in Y/N & -6.64 & -5.56 & -6.64 & -5.03 \\
due to TFP & -8.59 & -8.59 & -8.61 & -8.61 \\
due to K/Y & 5.55 & 6.95 & 5.57 & 5.81 \\
due to L/N & -3.60 & -3.92 & -3.60 & -2.23 \\
\hline
\end{tabular}




\section{Table 3}

\section{Growth accounting: \\ Decomposition of average annual changes in real output per working-age person (percent): model with land}

\begin{tabular}{|l|rr|rr|}
\hline & \multicolumn{2}{|c|}{ base case } & \multicolumn{2}{c|}{ adjustment costs } \\
& data & model & data & model \\
\hline depression 1974-1990 & & & & \\
change in Y/N & -1.60 & -2.86 & -1.60 & -2.21 \\
due to TFP & -2.49 & -2.49 & -2.53 & -2.53 \\
due to K/Y & 1.38 & 1.01 & 1.42 & 0.99 \\
due to $\mathrm{L} / \mathrm{N}$ & -0.32 & -1.21 & -0.32 & -0.50 \\
due to T/N & -0.17 & -0.17 & -0.17 & -0.17 \\
\hline boom 1990-1998 & & & & \\
change in Y/N & 3.90 & 6.39 & 3.90 & 5.05 \\
due to TFP & 6.28 & 6.28 & 6.25 & 6.25 \\
due to K/Y & -1.75 & -2.12 & -1.72 & -1.95 \\
due to $\mathrm{L} / \mathrm{N}$ & -0.39 & 2.47 & -0.39 & 0.99 \\
due to T/N & -0.24 & -0.24 & -0.24 & -0.24 \\
\hline depression 1998-2002 & & & & \\
change in Y/N & -6.64 & -6.20 & -6.64 & -4.97 \\
due to TFP & -6.24 & -6.24 & -6.26 & -6.26 \\
due to K/Y & 2.91 & 3.92 & 2.93 & 2.82 \\
due to $\mathrm{H} / \mathrm{N}$ & -3.09 & -3.66 & -3.09 & -1.31 \\
due to T/N & -0.22 & -0.22 & -0.22 & -0.22 \\
\hline
\end{tabular}


Figure 1

\section{United States: Real GDP per Working-Age Person}

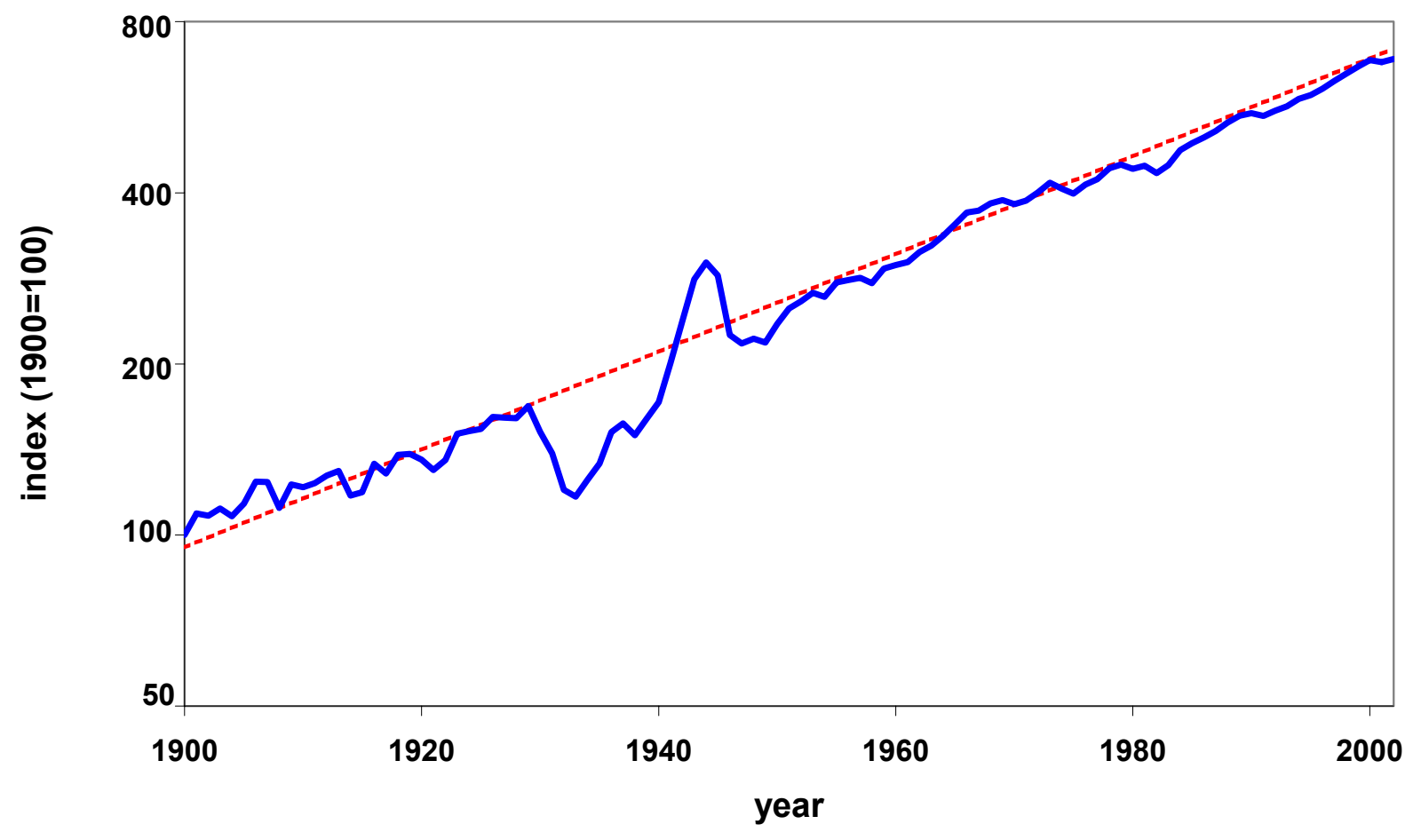


Figure 2

Argentina: Real GDP per Working-Age Person

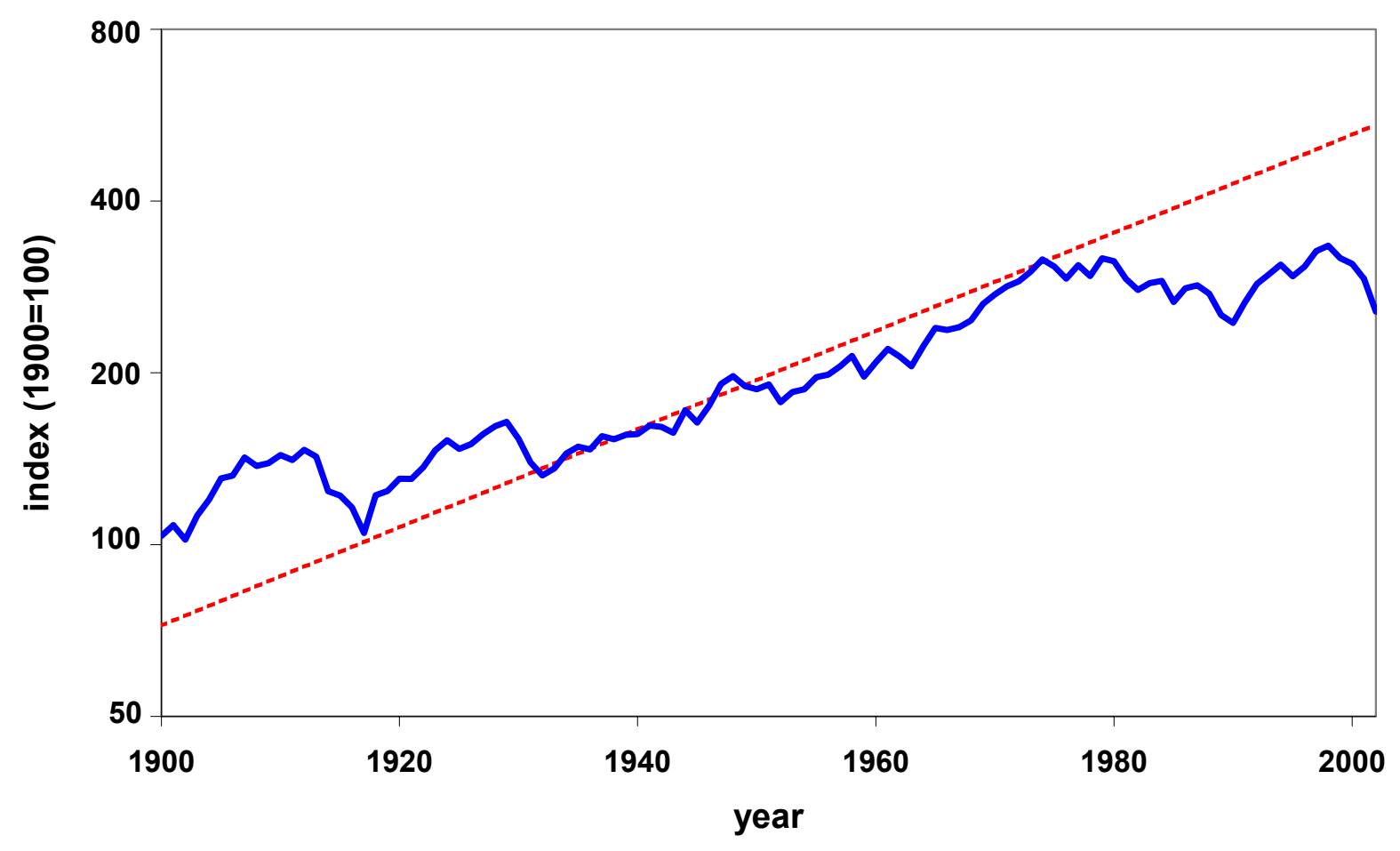


Figure 3

Real GDP Per Working Age Person and Total Factor Productivity in Argentina

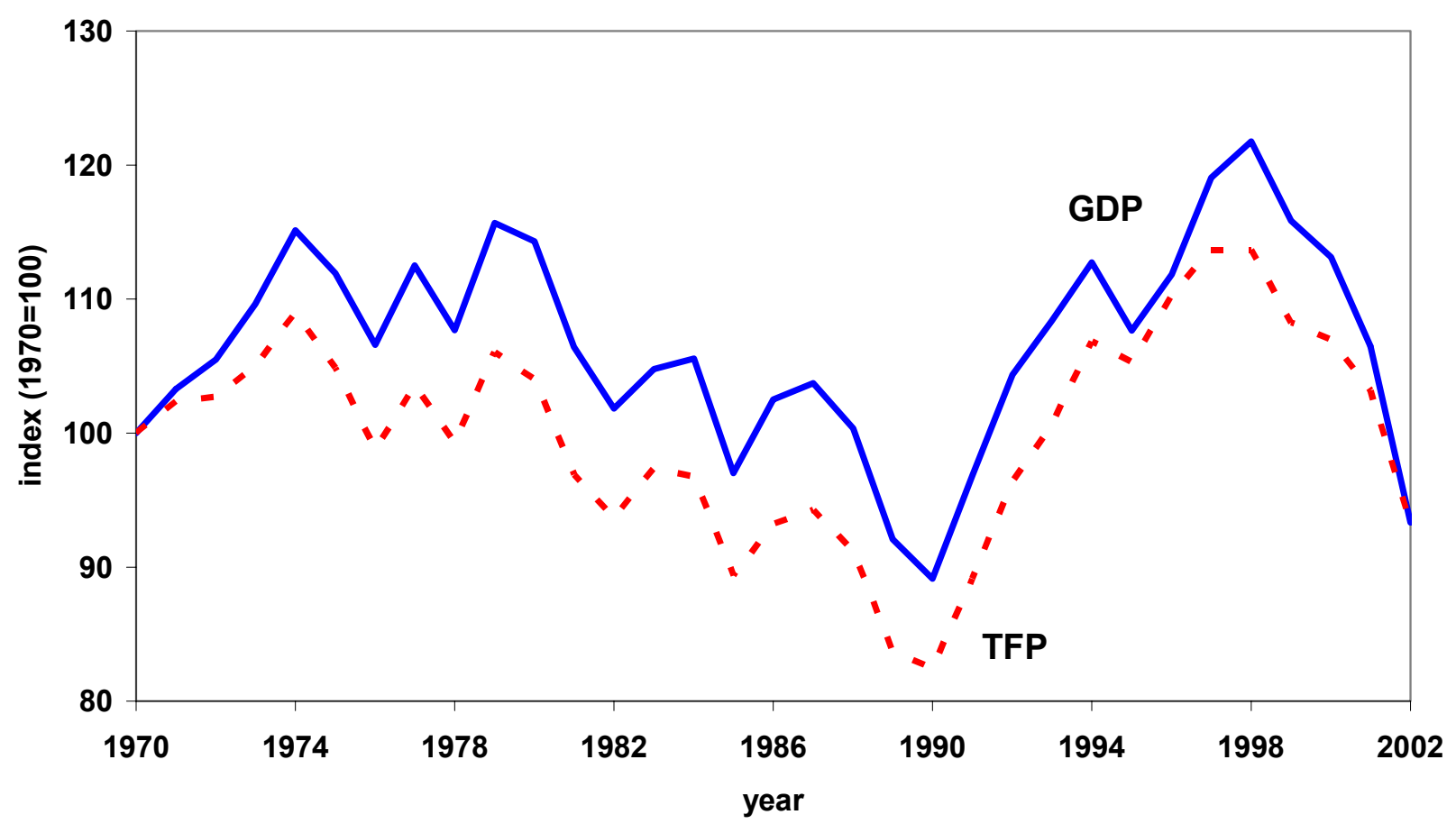


Figure 4

Real GDP per Working-Age Person

Base Case Model

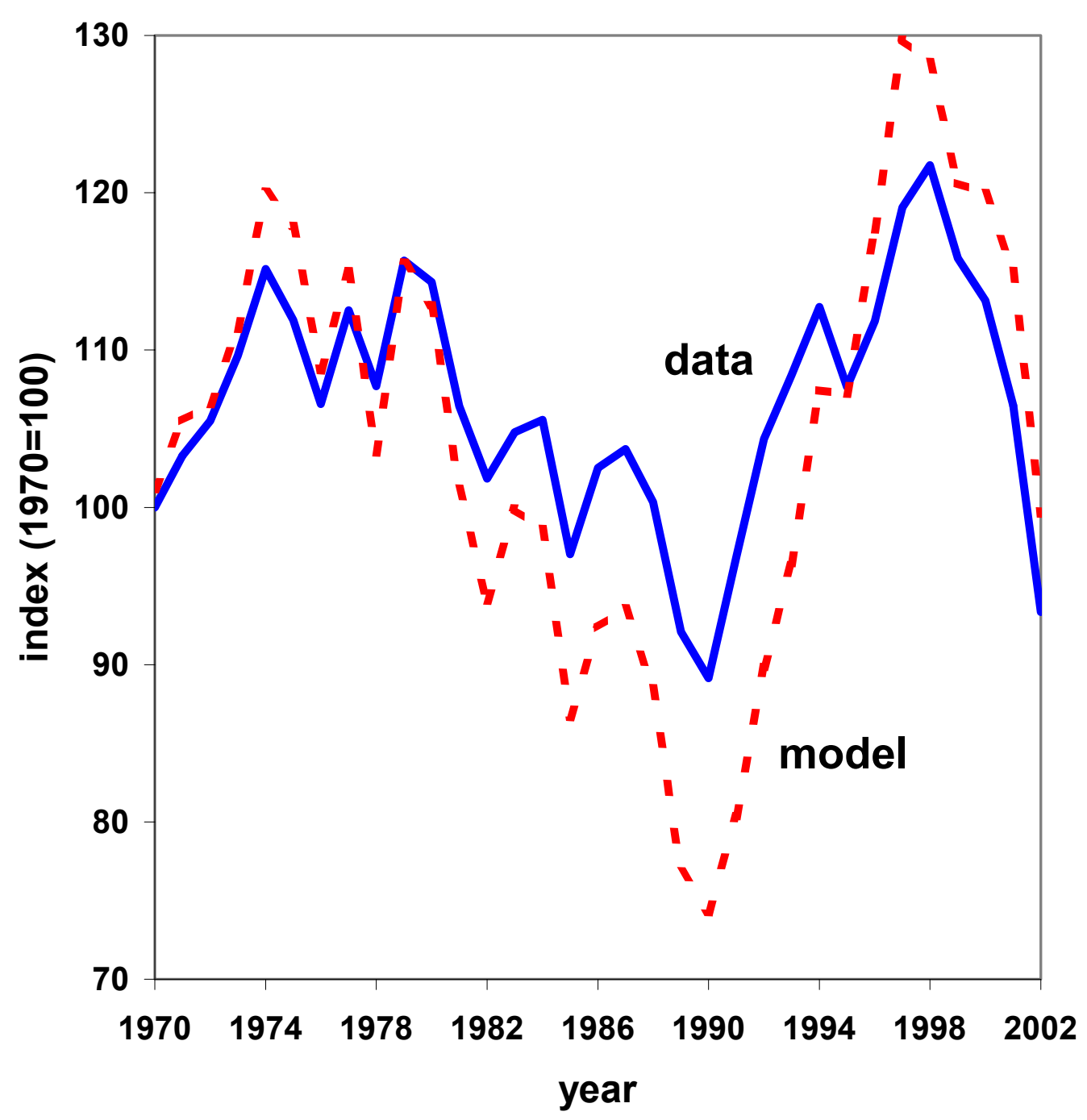

Model with Adjustment Costs

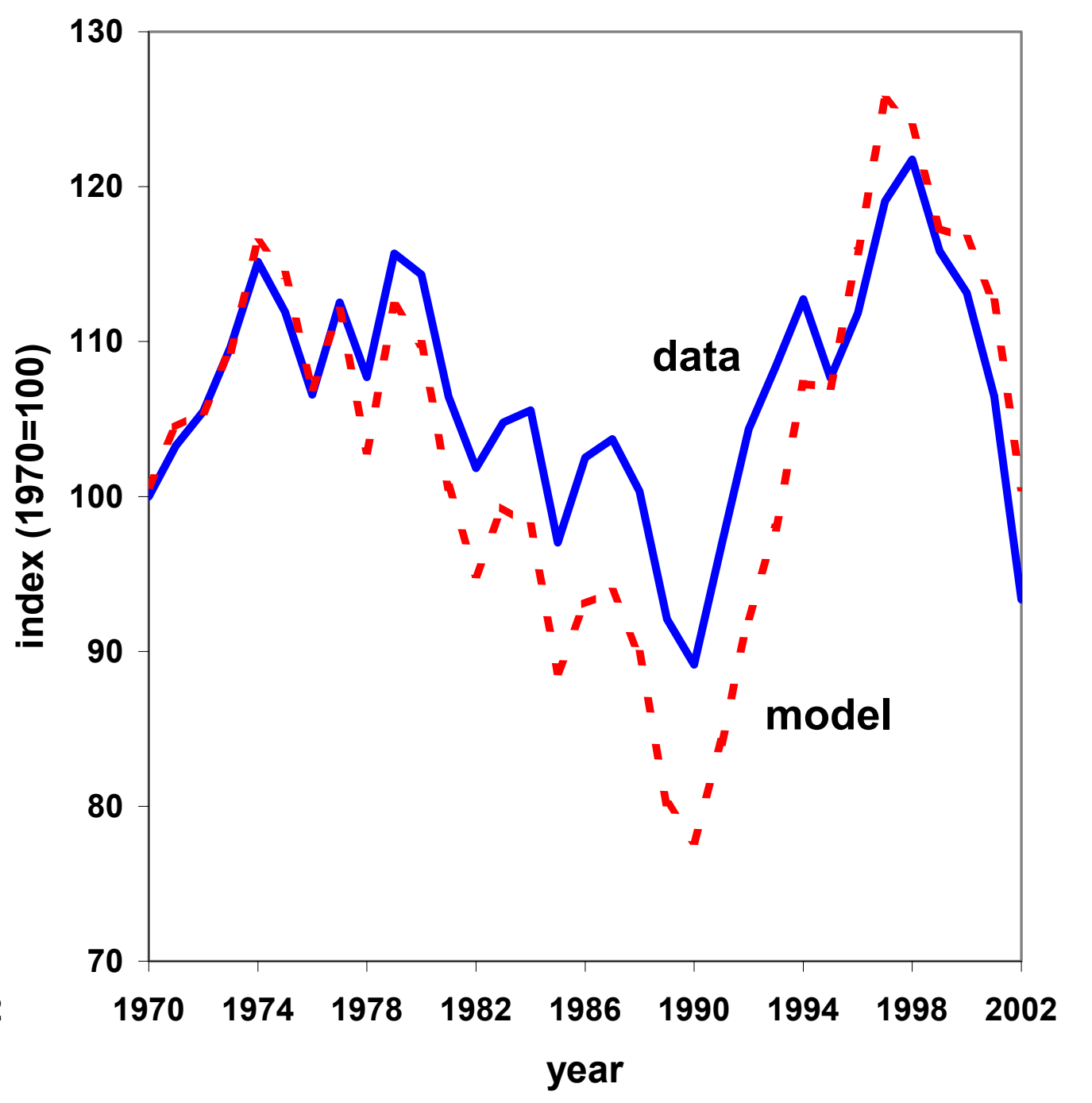


Figure 5

Hours Worked per Working-Age Person

Base Case Model

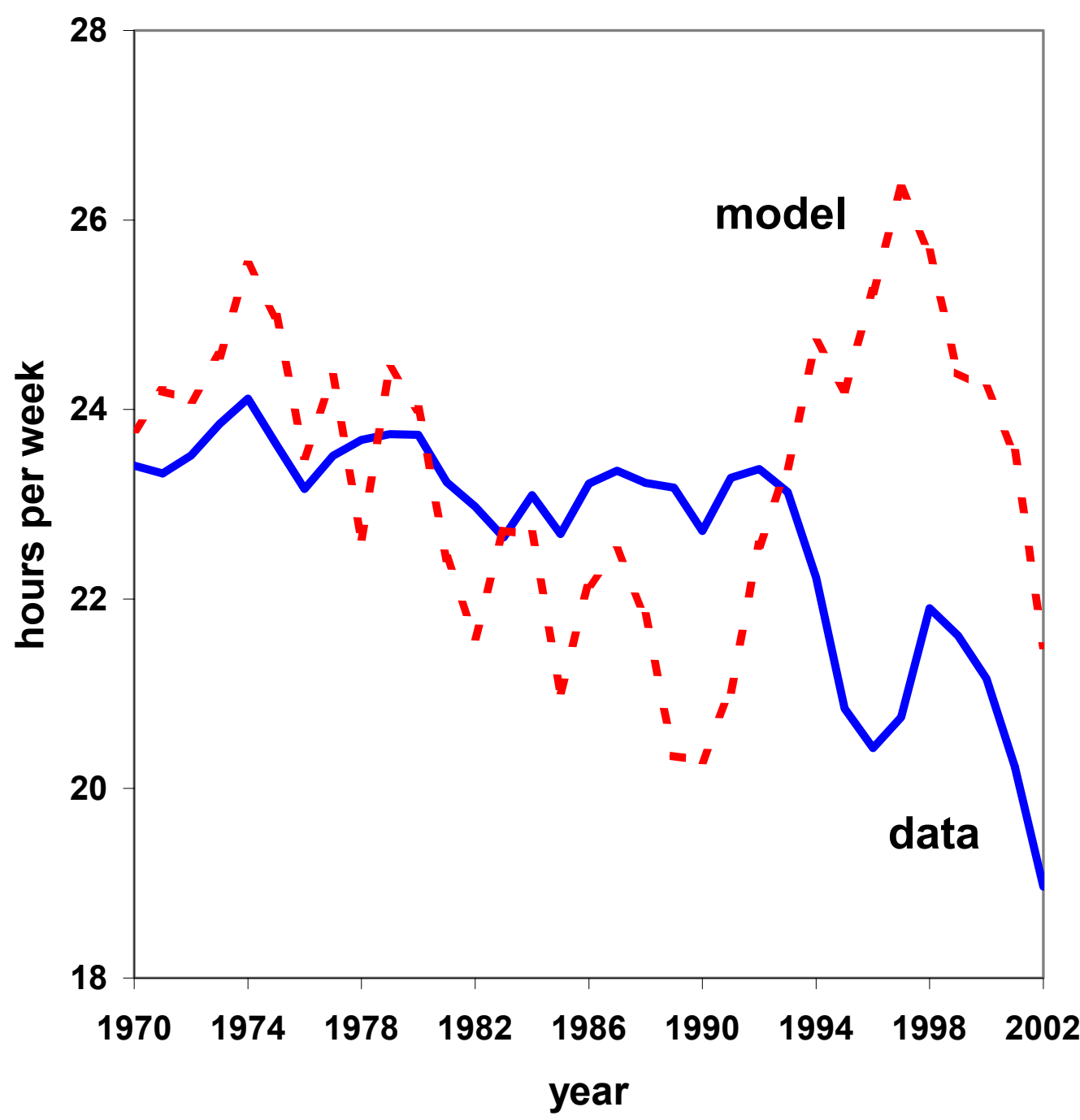

Model with Adjustment Costs

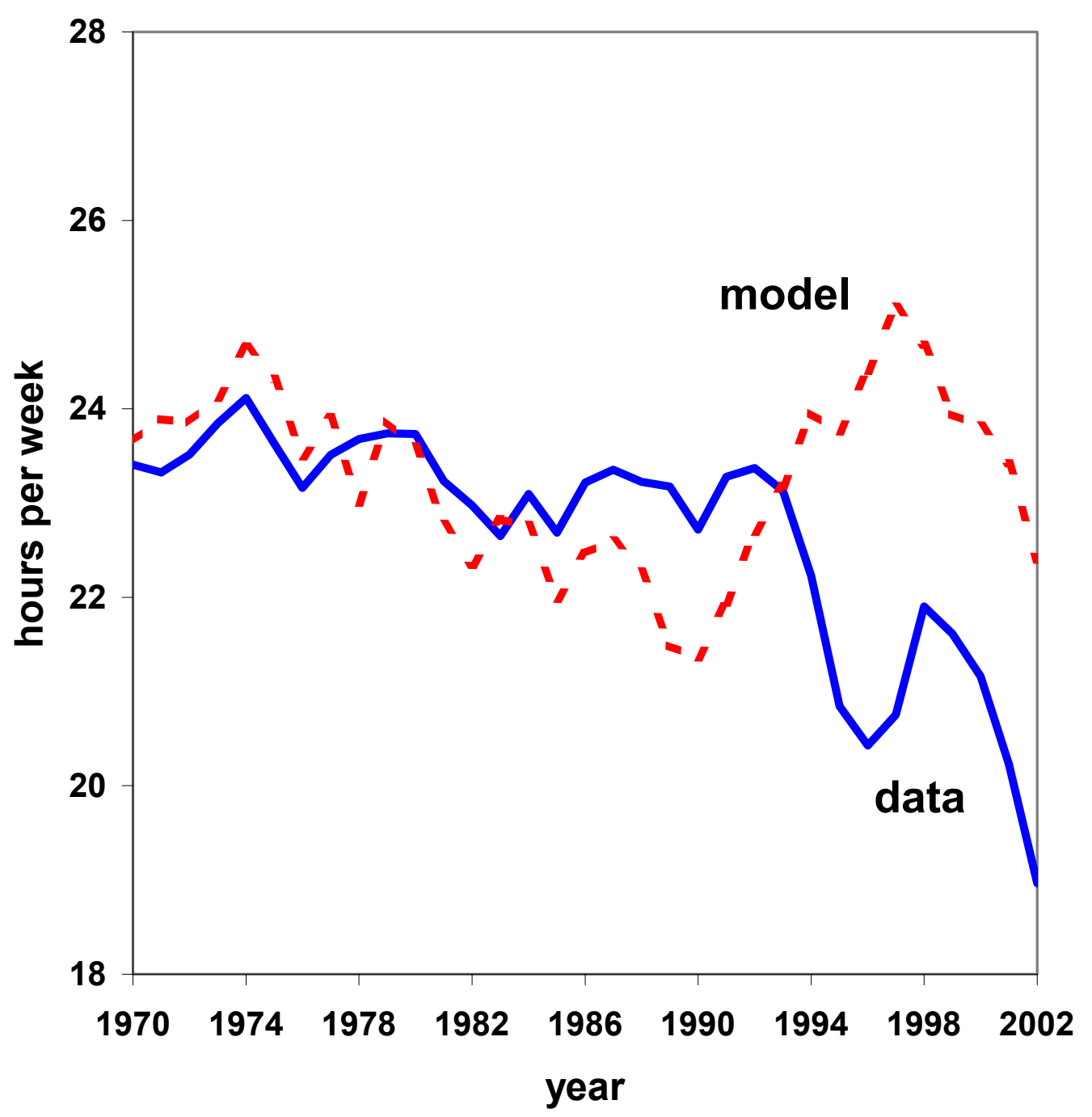


Figure 6

Capital-Output Ratio

Base Case Model

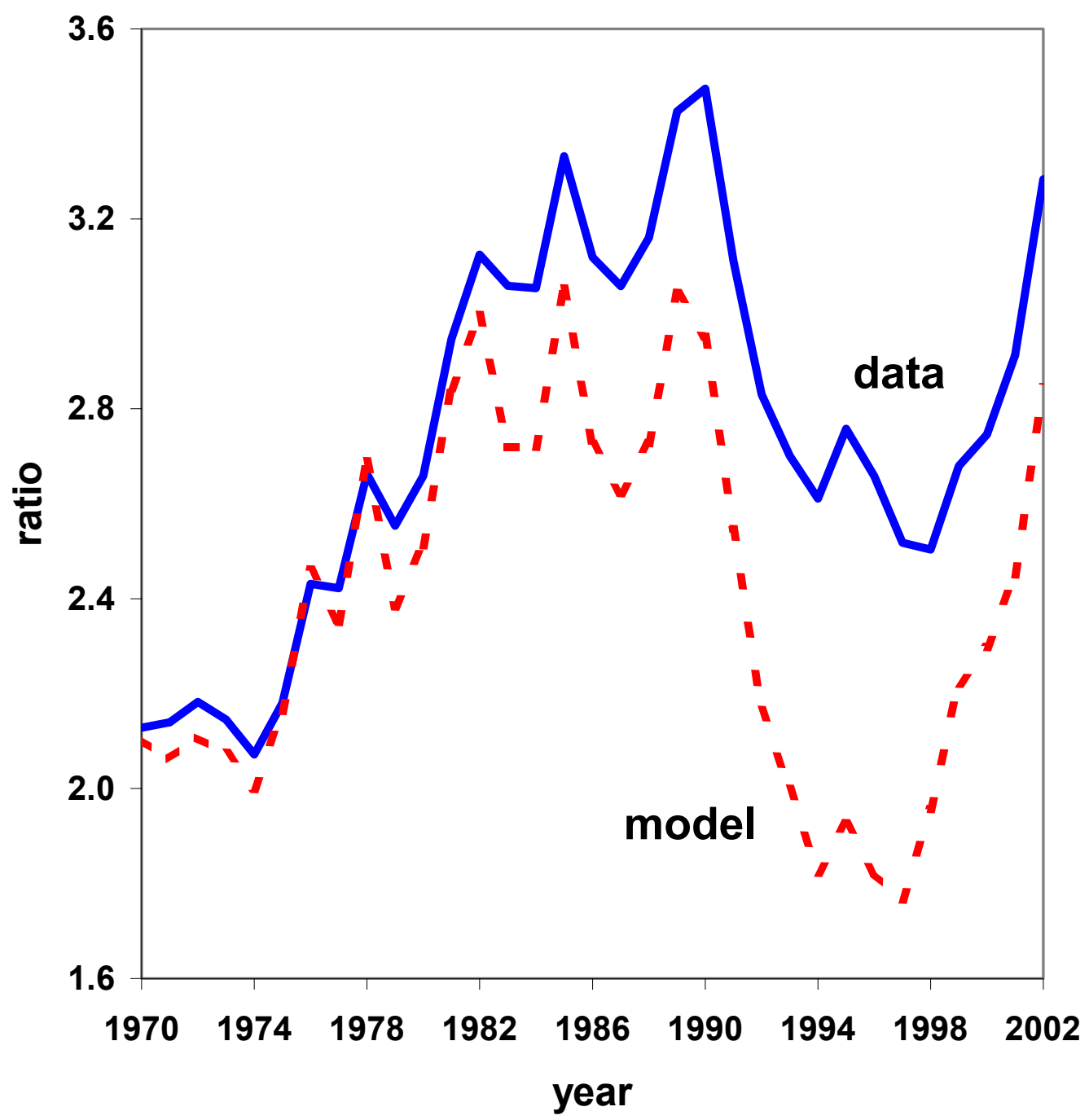

Model with Adjustment Costs

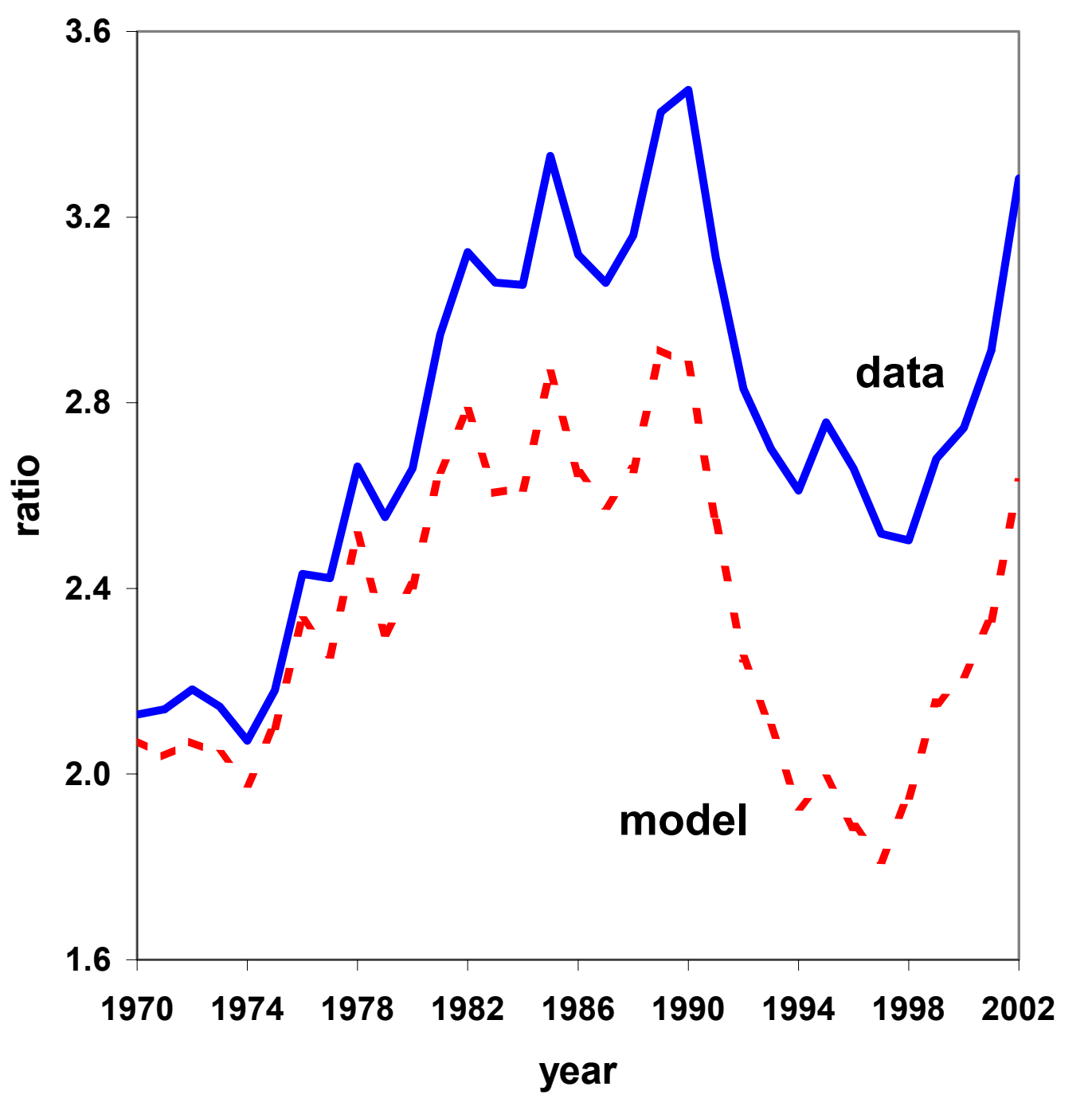


Figure 7

Investment Rate

Base Case Model

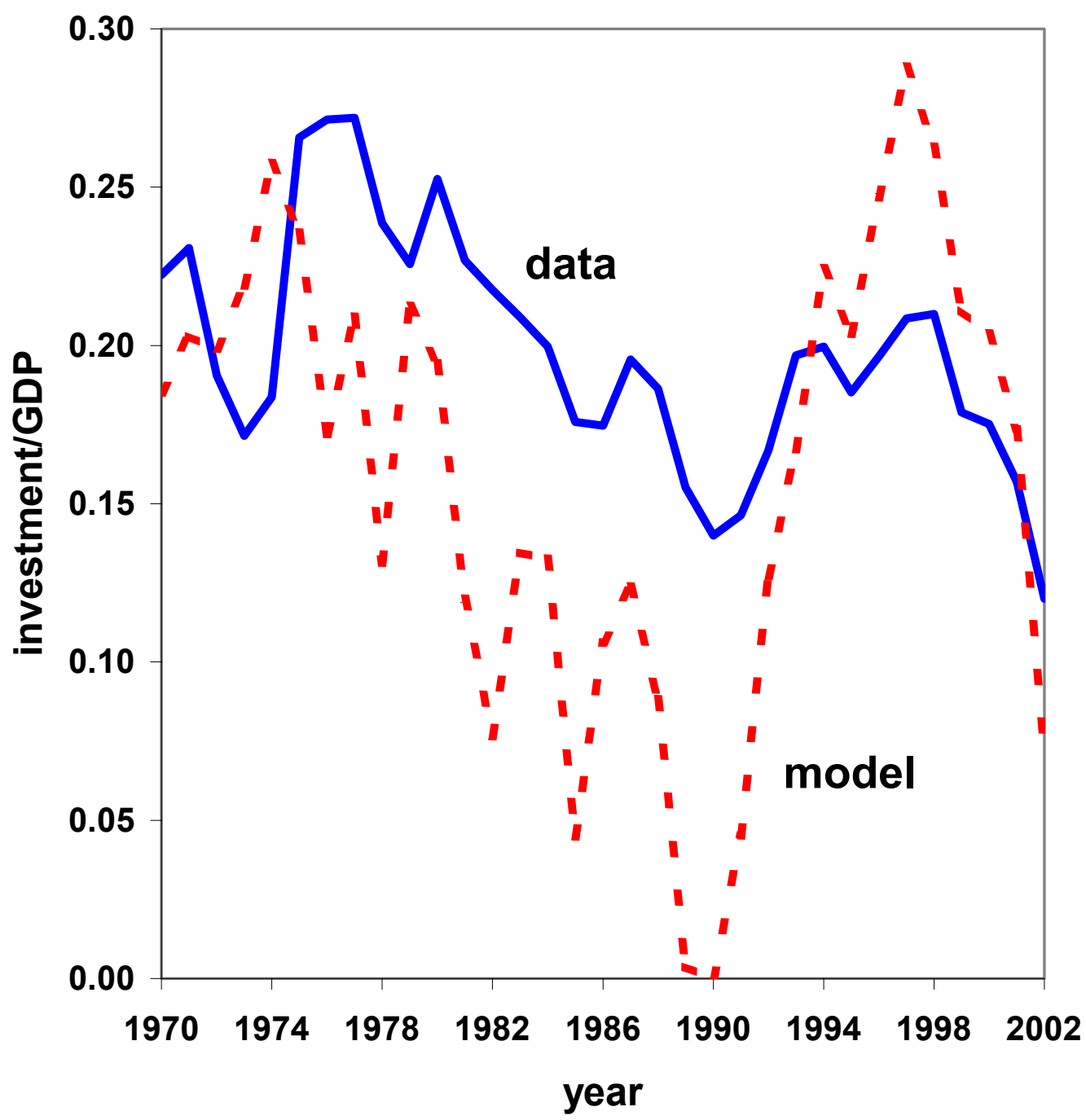

Model with Adjustment Costs

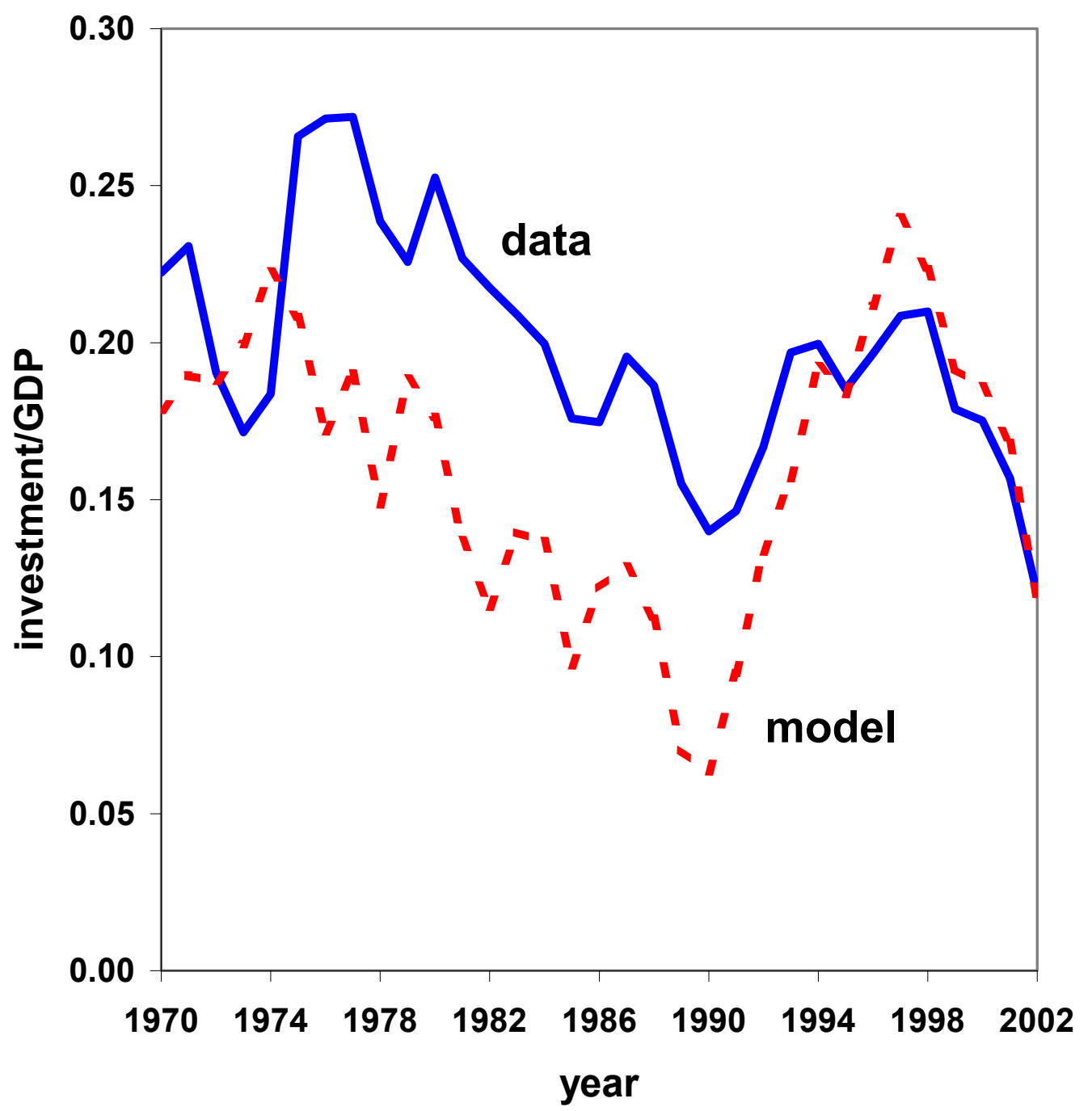


Figure 8

\section{CPI Inflation in Argentina}

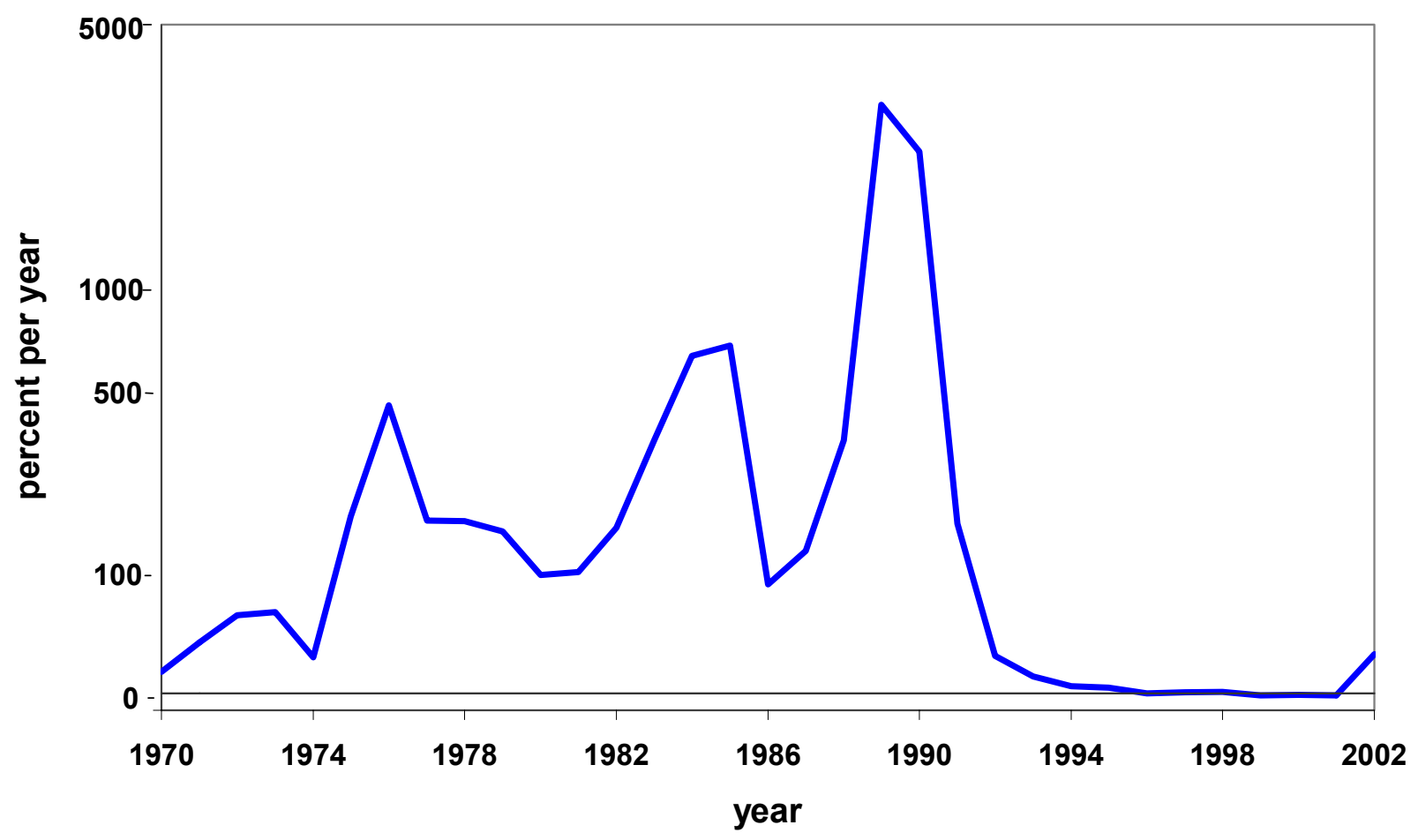


Figure 9

Money Market Interest Rates in Argentina

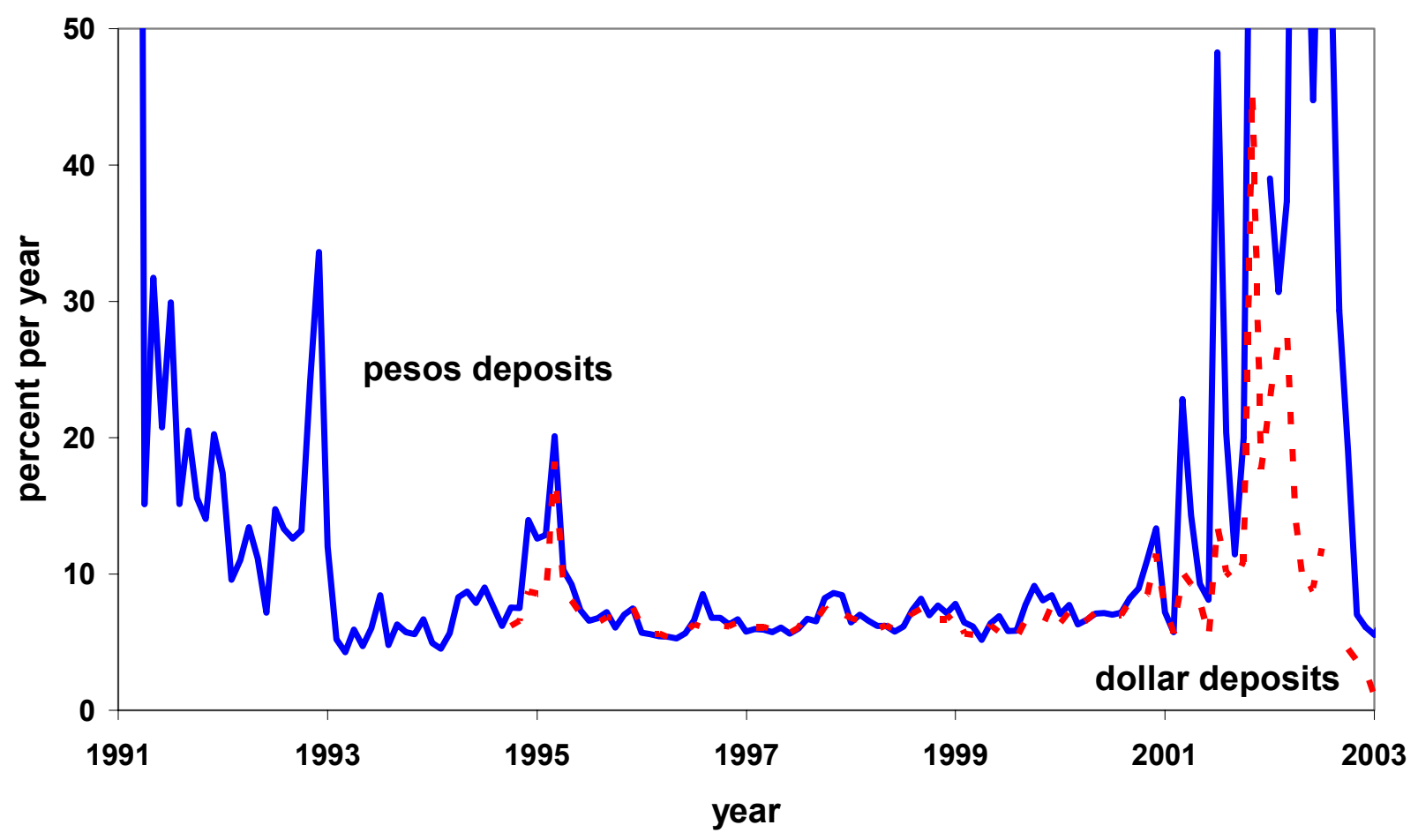


Figure 10

Trade in Goods and Services in Argentina

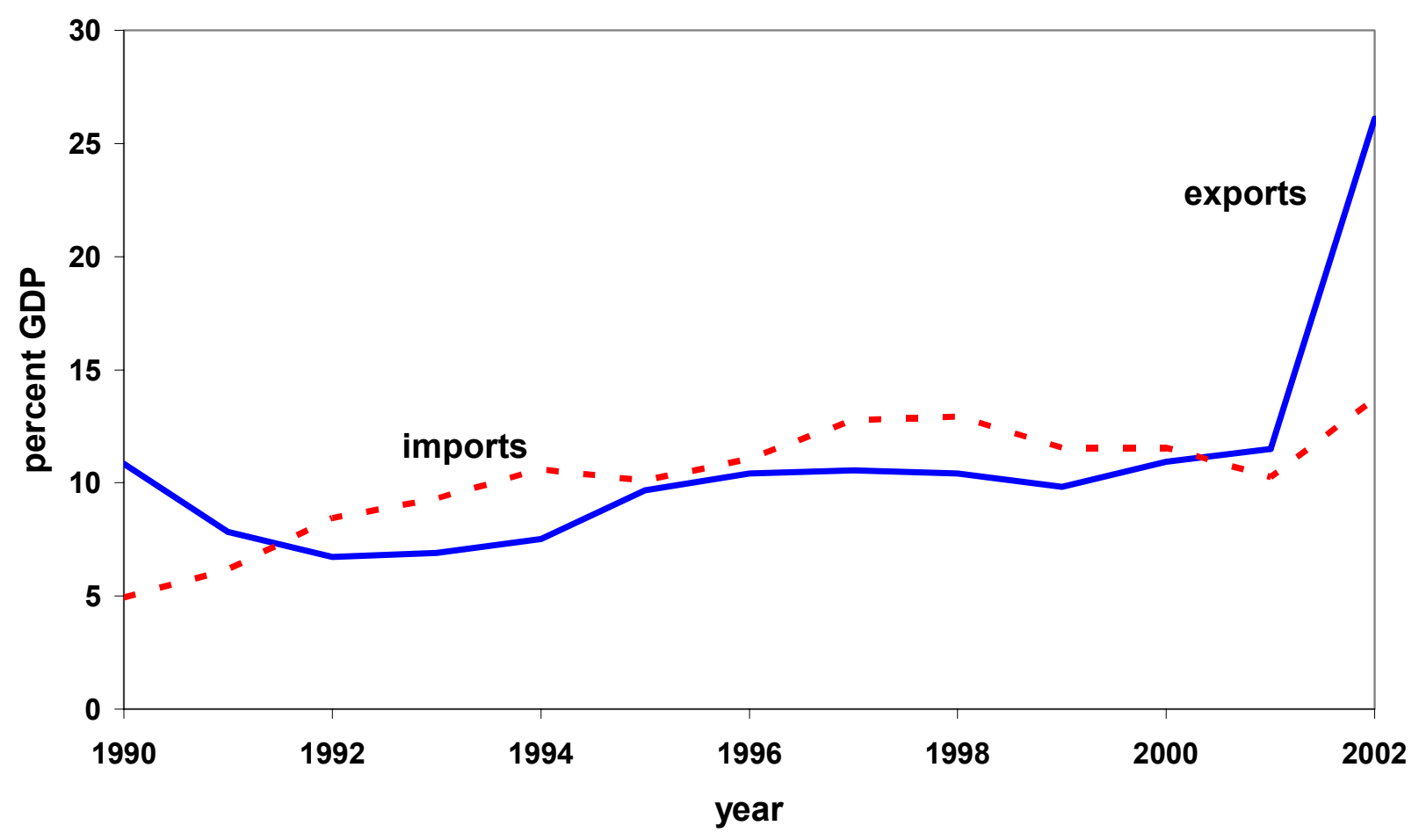


Figure 11

\section{Inward Foreign Direct Investment}

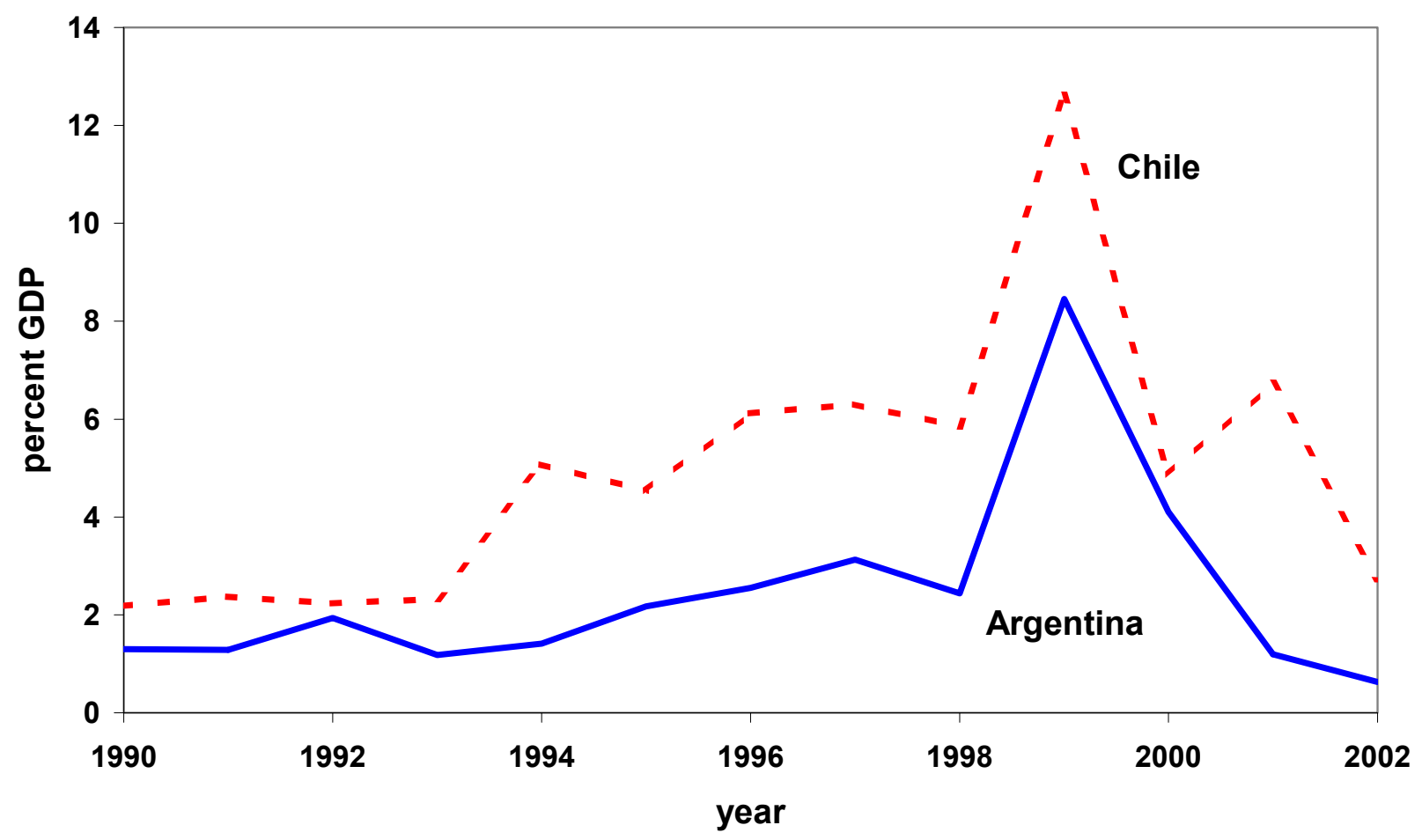


Figure 12

Federal Government Finances in Argentina

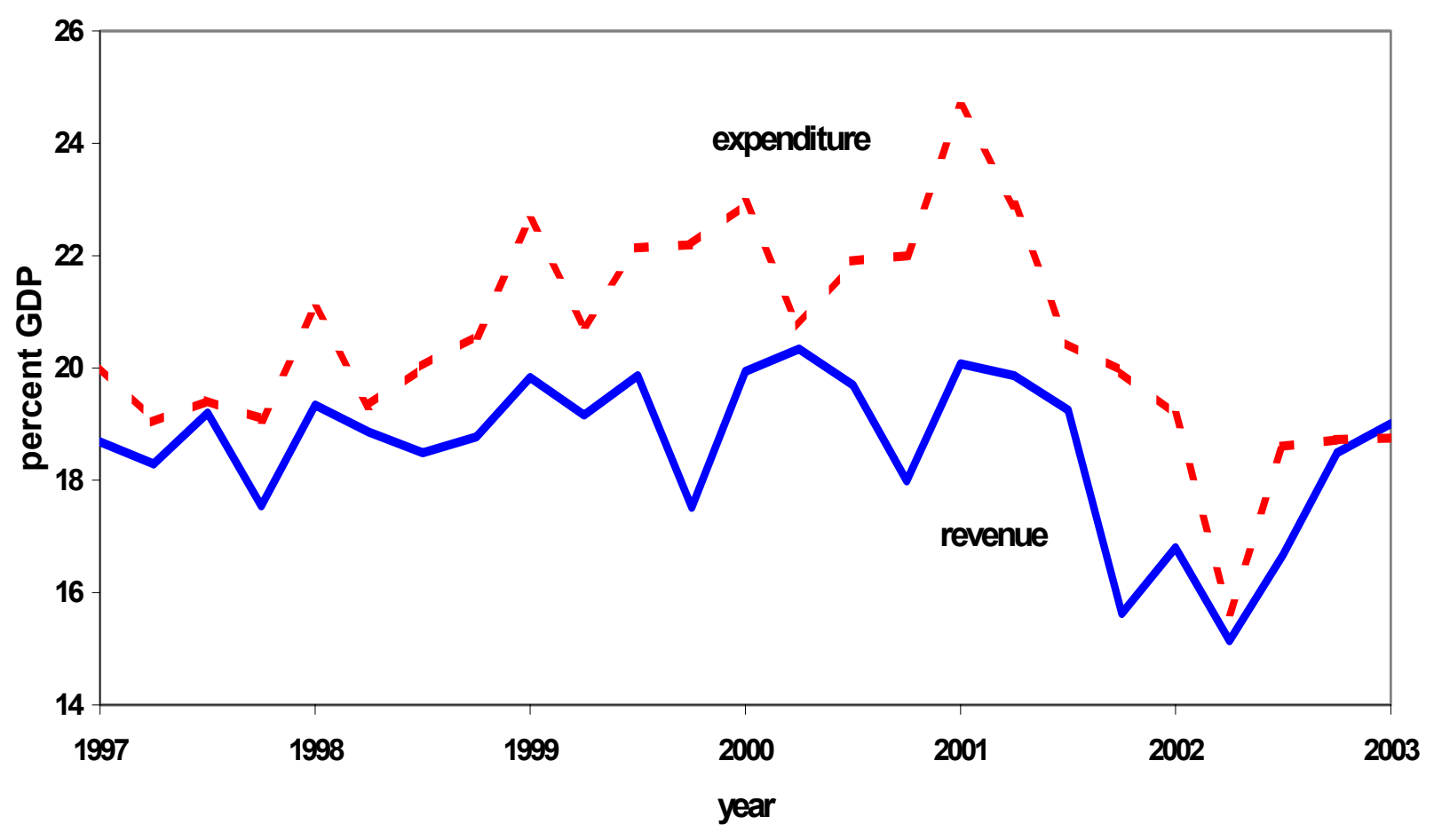


Figure 13

Overall Government Balance in Argentina (Including Off Budget Items)

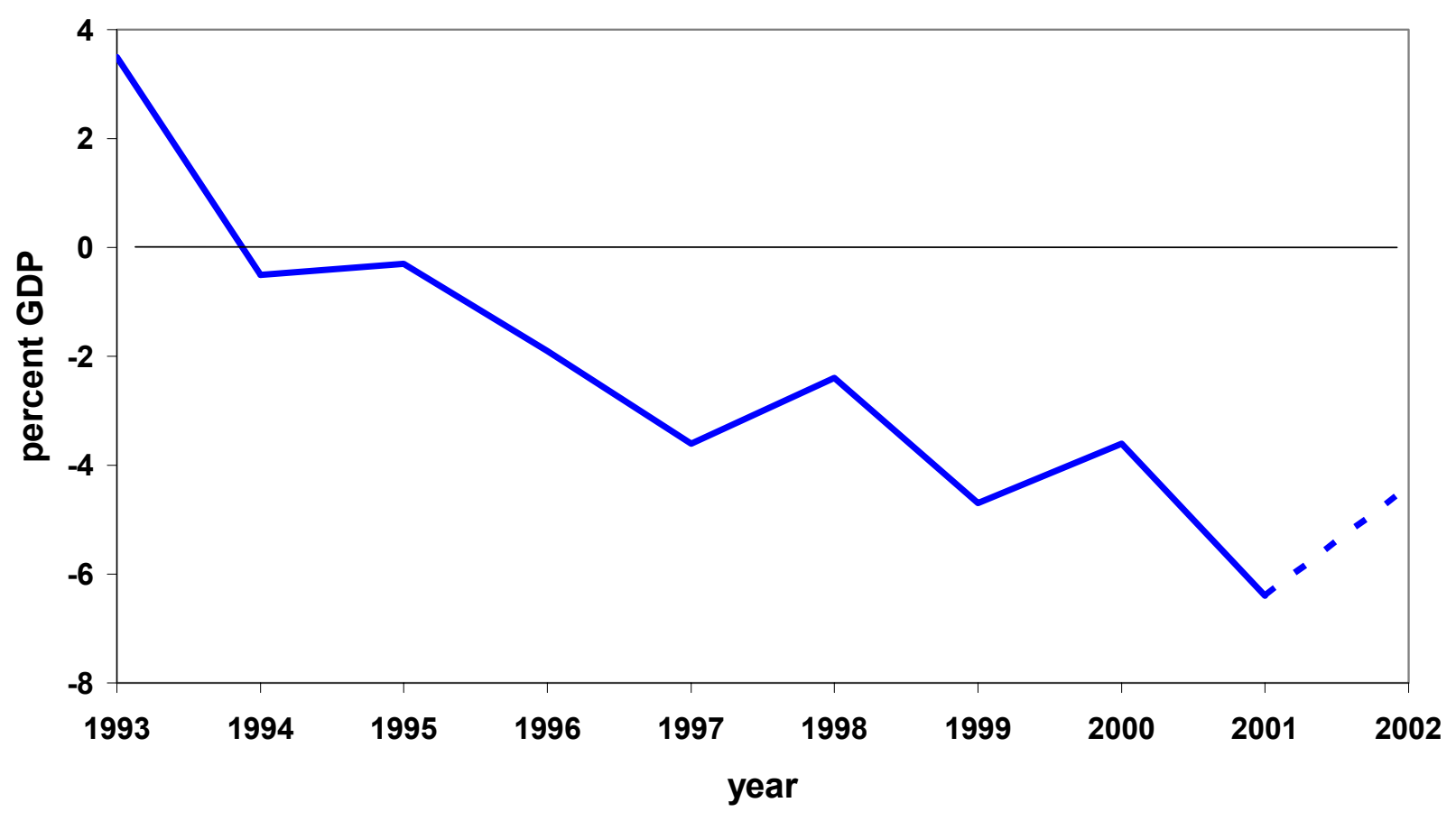


Figure 14

\section{External Debt/GDP in Argentina}

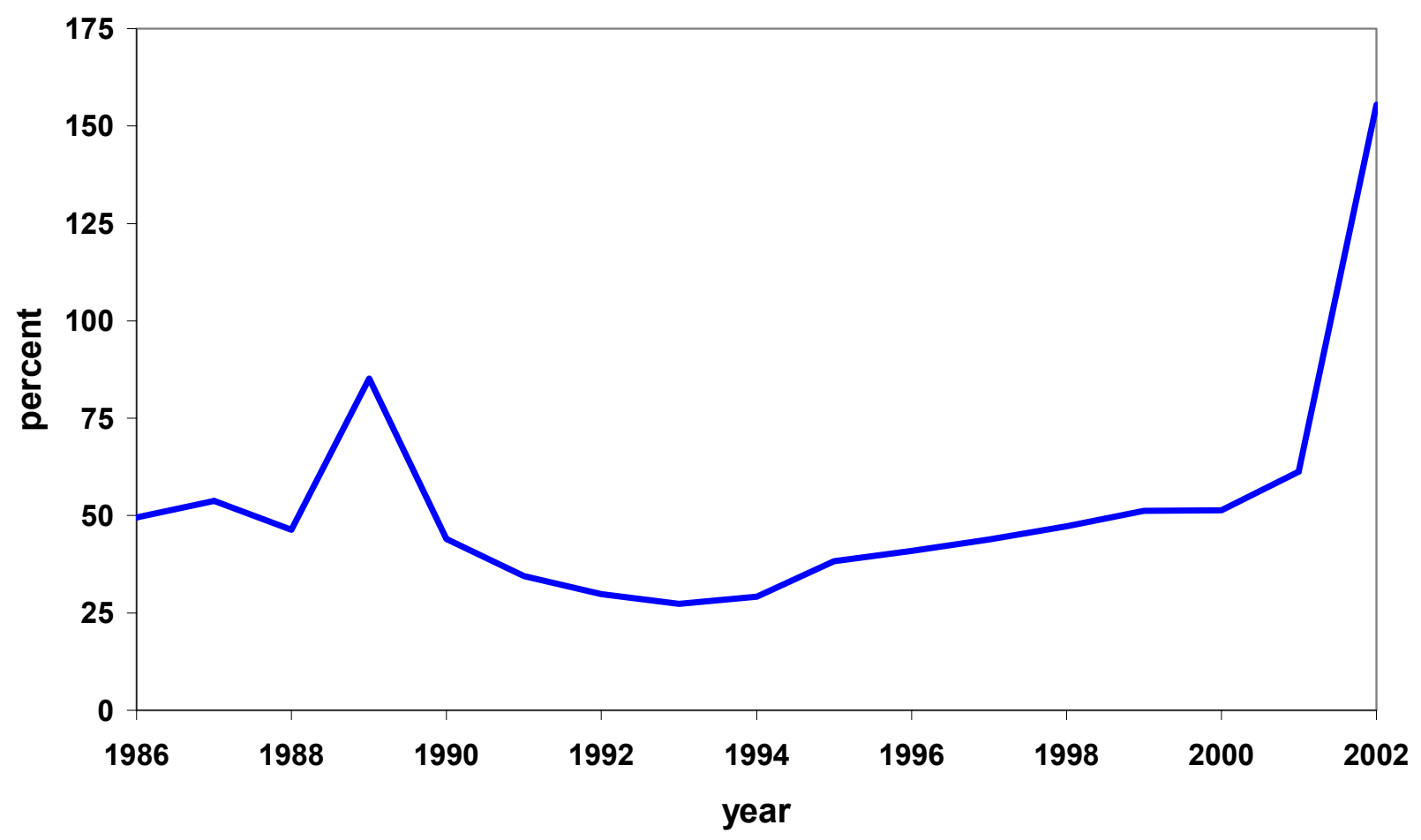


Figure 15
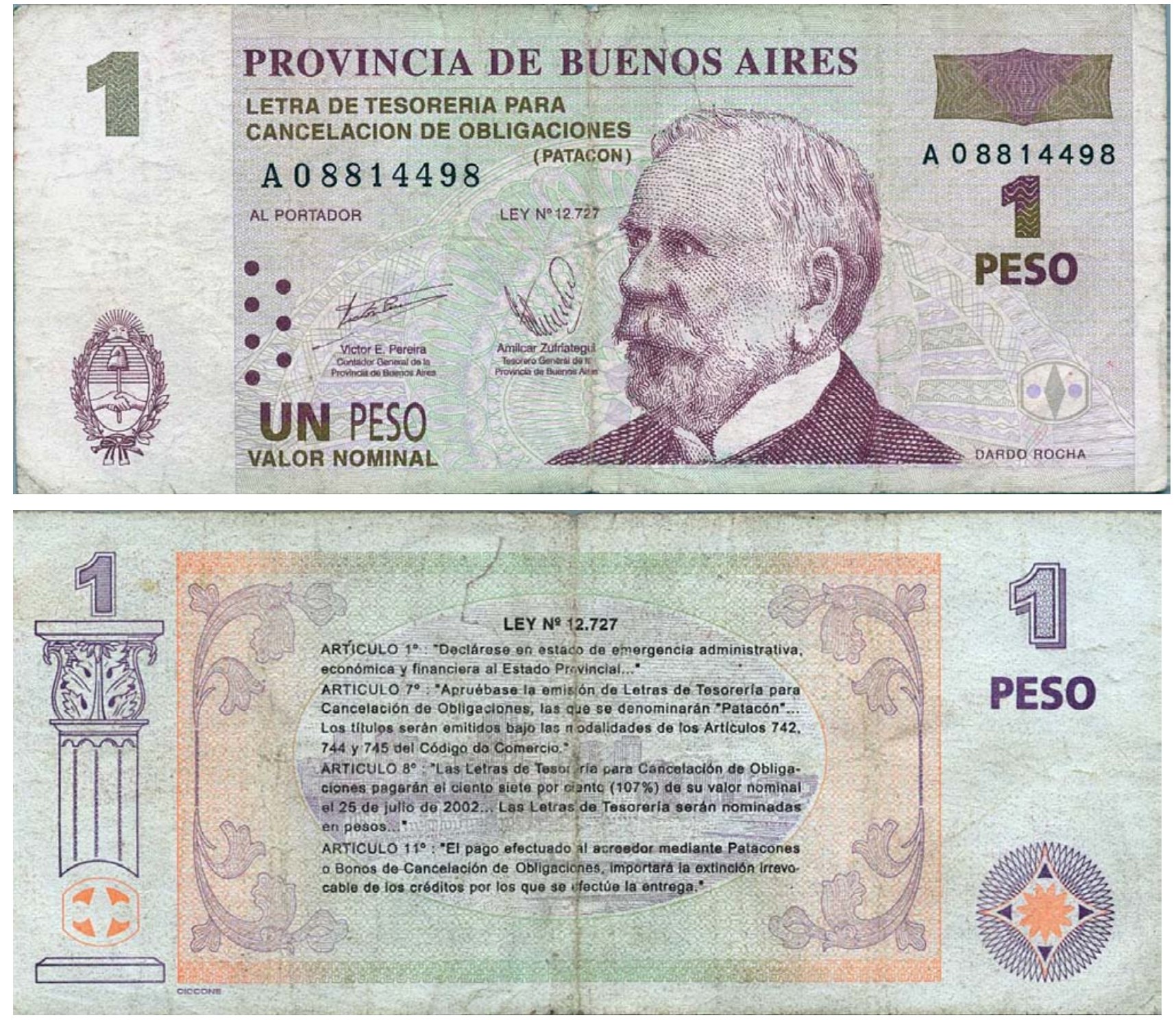
Figure 16

\section{Argentina-U.S. Real Exchange Rate}

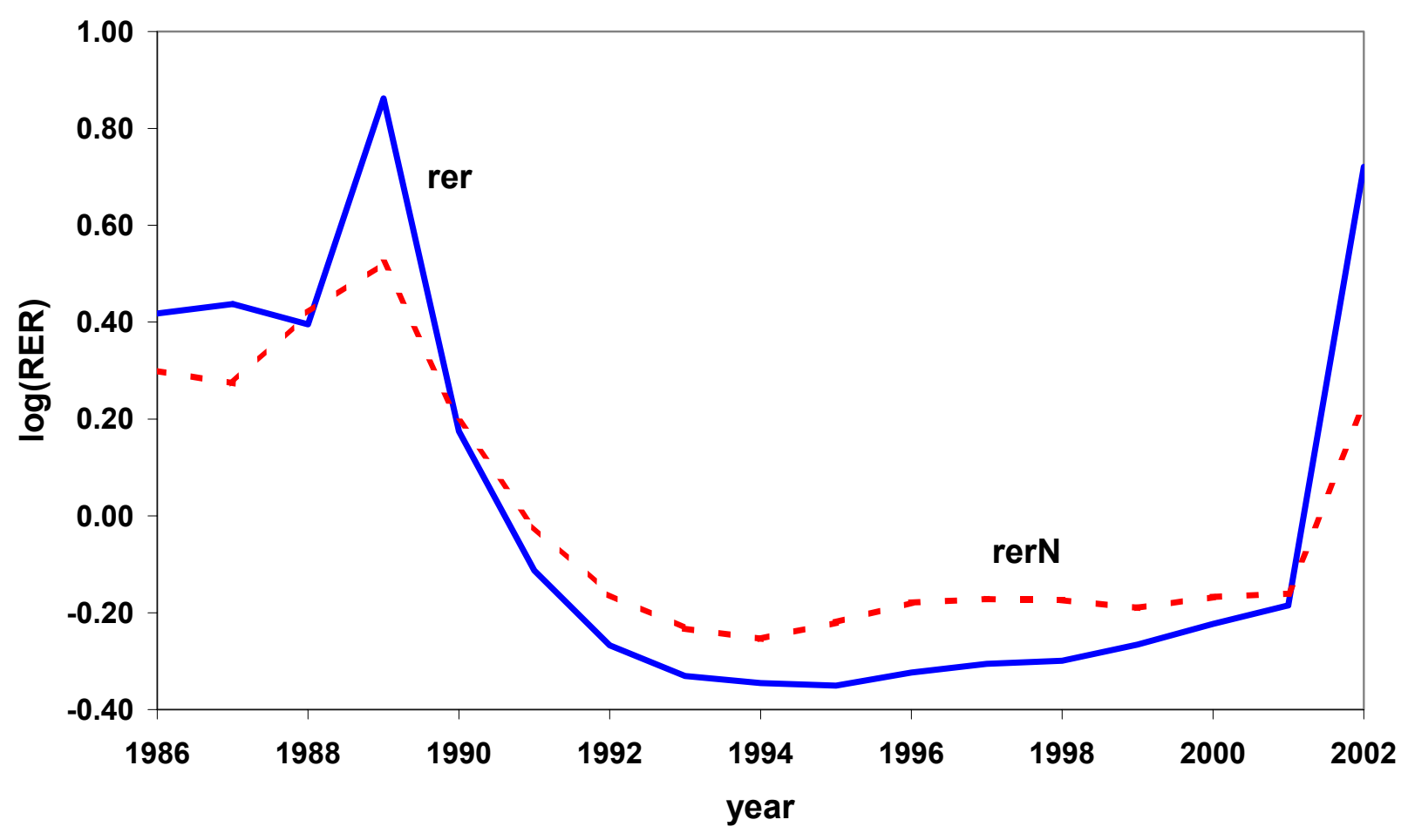

